\title{
Misvaluation and Return Anomalies in Distress Stocks
}

\author{
Assaf Eisdorfer \\ Amit Goyal \\ Alexei Zhdanov*
}

November 2011

\begin{abstract}
Return anomalies are most pronounced among distressed stocks. We attribute this finding to the role of misvaluation and investors' inability to value distressed stocks correctly. We treat distressed stocks as options and construct a valuation model that explicitly takes into account the value of the option to default (or abandon the firm). We show that anomalies exist only among the subset of distressed stocks classified as misvalued by our model. There is little evidence that more misvalued stocks are harder to arbitrage than less misvalued stocks.
\end{abstract}

*Assaf Eisdorfer is from University of Connecticut, email: Assaf.Eisdorfer@business.uconn.edu, Tel: 860-486-4485; Amit Goyal is from Swisss Finance Institute at the University of Lausanne, email: Amit.Goyal@unil.ch, Tel: +41-21-692-3676; and Alexei Zhdanov is from Swisss Finance Institute at the University of Lausanne, email: Alexei.Zhdanov@unil.ch, Tel: +41-21-692-3674. Amit Goyal would like to thank Rajna Gibson for her support through her NCCR-FINRSK project. We thank Norman Schürhoff for helpful comments. All errors are our own. 


\section{Introduction}

Financially distressed firms earn low returns. This well-documented (we discuss the relevant literature later) empirical finding is puzzling for asset pricing theories because, ex-ante, one would assume that investors should demand return compensation for bearing credit risk. At the same time, several asset pricing anomalies such as the size-effect, the value premium, and momentum are more pronounced amongst low credit rating firms (Avramov et al. (2010)) .

Several explanations have been proposed in the literature for these empirical phenomena. First, there might be a common distress risk factor, exposure to which causes returns of low credit risk firms to move together. Indeed, Campbell, Hilscher, and Szilagyi (2008, henceforth $\mathrm{CHS}$ ) find that financially distressed firms have high market betas and high loadings on SMB and HML factors. However, distressed firms earn low returns in contrast to these risk-based explanations. ${ }^{1}$ Moreover, Avramov et al. report that low returns to these firms are concentrated around credit rating downgrades, which tend to be idiosyncratic events.

Second, distressed firms may be hard to arbitrage. Several studies document that distress anomaly is stronger for stocks with low institutional holdings, fewer analysts, and higher illiquidity (see, for example, CHS). While the limits to arbitrage might be relevant for explaining why anomalies within distress firms persist over time, it is not obvious how useful this argument is explaining why these anomalies arise in the first place.

Third, distress anomaly might have a behavioral explanation. Lakonishok, Shleifer, and Vishny (1994) argue that mispricing is the result of naïve extrapolation of past performance by investors. However, Griffin and Lemmon (2002) show that distressed firms have had poor past performance yet are awarded high valuations by investors. CHS also cast doubt on this argument by showing that returns to distressed firms are not concentrated around earnings announcements.

In this paper, we explore a variant of behavioral explanation for why the asset pricing anomalies are concentrated amongst distressed stocks. Our contention is that distressed firms are hard to value. Most of the distressed companies have had negative earnings in the past implying the unsuitability of the popular random-walk model of earnings forecast. Standard valuation techniques such as multiples-valuation or discounted cashflow are, therefore, not well-suited for distressed companies. This coupled with the fact that these firms have low analyst coverage (median number of analysts covering the most distressed firm in our sample

\footnotetext{
${ }^{1}$ See Kapadia (2011) for an alternate view. Kapadia constructs an aggregate distress risk factor based on business failures. He finds that this portfolio hedges distress risk and exposures to this factor explain size-effect and value premium. He also reports that financially distressed firms do not have high exposures to his distress factor. The issue of why financially distressed firms have low returns is, thus, left unanswered.
} 
is 1.5) suggests that few investors have the skills to value these stocks correctly.

A key characteristic of distressed firms is their option to default. Any valuation model that ignores the value of this option is going to produce values that are further away from fundamental value than a model that explicitly accounts for this option. We contend that it is more appropriate to think of the equity of these firms as an option. For highly distressed stocks the option to default is in-the-money. Traditional discounted cashflow (DCF) approach suffers from at least two problems for such companies. First, ignoring the value of the option to default results in highly biased values. Second, using a constant discount rate is incorrect because the risk of equity changes as the firm moves closer or further away from default. We address these two issues by explicitly modeling the value of the option to default and by performing valuation under the risk-neutral measure. The main goal of our paper is to use this option-based valuation model for investigating the anomalous stock returns to distressed firms in relation to their relative valuation (market versus our valuation measure).

We start our analysis by verifying prior evidence on returns to distressed stocks. We sort stocks based on the distress risk measure proposed by CHS (2008). This measure uses both accounting and equity market variables to forecast bankruptcy over different horizons. We find that a long-short portfolio that is long in the decile of least distressed stocks and short in most distressed stocks earns $1.44 \%$ per month. These returns are not subsumed by the Fama and French (1993) factors or the momentum factor. We also find that the size effect, the value premium, and momentum are stronger in more distressed firms. For example, monthly excess returns of the winners-losers portfolio are $1.19 \%$ for the most distressed firms but $-0.19 \%$ for the least distressed firms. These facts, which serve as foundation of our main analysis, are consistent with the extant evidence (see, for example, Griffin and Lemmon (2002), Avramov et al. (2007, 2010)).

We then turn our attention to the most distressed firms. As mentioned before, we use an option pricing model that recognizes the option-like nature of distressed equities. Option pricing have been employed in the literature to gauge the probability of default and to value corporate bonds given the value the equity (see for example, Merton (1974), Geske (1978), and Delianedis and Geske (2003), among others). We, instead, use an option pricing model to value the equity itself. Our model uses standard features of structural models - stochastic cash flows, fixed costs, and debt. We also alow for endogenous default, different tranches of debt with different maturities, and additional costs of financial distress.

Our valuation model allows us to classify the distressed firms further into under- and overvalued based on the value produced by our model and the market value of equity. We find that stocks that we classify as overvalued are larger, have higher market-to-book ratios, 
and issue more equity than stocks that we classify as undervalued. Excess returns on these sub-categories of stocks show patterns consistent with our valuation model. For example, the excess return for overvalued quintile of distressed stocks is $-1.16 \%$ while that for undervalued quintile of distressed stocks is close to zero. These differences are not explained by factors as factor model alphas are economically large and, for the large part, statistically significant.

Our main hypothesis is that anomalies in distressed stocks are concentrated in stocks that are the most misvalued. Distress stocks have option-like features. The resulting valuation difficulties imply that anomalies are more widespread in distressed stocks. Our valuation model allows us to separate fairly valued versus misvalued distressed stocks. We expect, therefore, that, within the subset of distressed stocks, anomalies are stronger in stocks that are the most misvalued.

To verify our conjecture, we dig deeper within the subset of most distressed stocks. Within this subset, we sort stocks further into terciles based on whether they are fairly valued or misvalued (where the relative valuation is determined by the comparison of market value and model value). We then look at the strength of anomalies in these three terciles. The results are consistent with our conjecture. The excess returns to the small-big portfolio are $1.29 \%(0.66 \%)$ in misvalued (fairly valued) stocks; the excess returns to the value-growth portfolio are $1.29 \%(-0.19 \%)$ in misvalued (fairly valued) stocks; and the excess returns to the winners-losers portfolio are $0.94 \%$ (0.35\%) in misvalued (fairly valued) stocks. Our results are robust to various subsamples and persist across longer horizons than just one quarter. They are also robust to alternative defintions of distress.

It is tempting to conclude that our results are just another manifestation of the limits to arbitrage. We believe this not to be the case. It is true that distressed stocks are small, illiquid, have low institutional ownership, fewer analyst coverage, and higher idiosyncratic risk, all proxies for higher arbitrage risk. However, what we report in this paper is that anomalies are located only in a subset of distressed stocks, namely the misvalued stocks. We find no cross-sectional differences in arbitrage risk across groups of distressed stocks sorted by relative valuation. We take this evidence to be more suggestive of misvaluation story rather than a limited arbitrage story.

An interesting question raised by our study is why investors do not use option valuation models to value distressed stocks. One potential explanation is the complexity involved in generating such models. We hypothesize that many investors, especially retail investors, do not possess the necessary skills to implement such a model (distressed stocks have very low institutional ownership). This conjecture is consistent with the evidence presented by Poteshman and Serbin (2003) who document that investors often exercise call options in 
a clearly irrational manner, suggesting that it is hard for certain types of investors to understand and value options correctly (Poteshman and Serbin find that this is particularly true for retail investors, while traders at large investment houses do not exhibit irrational behavior.) Furthermore, Benartzi and Thaler (2001) show that when faced with a portfolio optimization problem, many investors follow naïve and clearly suboptimal strategies again suggesting that investors fail to fully understand more sophisticated models. On the other hand, as modeled by Hirshleifer and Teoh (2003), limited attention and processing power may lead investors to ignore or underweight information that is important for an optionbased model to produce unbiased valuations (for example, one of key inputs in our model is volatility of sales). ${ }^{2}$

We would like to emphasize that our valuation model does a good job of relative valuation by separating under- and overvalued stocks amongst the subset of distressed securities. At the same time, though, the average returns of stocks classified as fairly valued by our model are also negative. This implies that our valuation model still misses common factors that could explain the overall low/negative returns of distressed stocks. Explaining this low-return puzzle is outside of the scope of our paper. Instead, we focus on examining the driving force behind return anomalies being the strongest among distressed securities. Finally, we reiterate that the power of our model is in the valuation of the option to default and/or shut down the firm. For stocks far from the default boundary (stocks with positive cash flows, low volatility, and low leverage ratios), normal valuation techniques such as discounted cashflow may still be adequate and not much may be gained by using our model for such stocks.

The literature on distress risk and stock returns got an impetus from the seminal work by Fama and French (1993), where they suggest that the value factor might be related to firms facing financial distress. However, Dichev (1998) reports that, on the contrary, distressed firms earn low returns. These findings have been corroborated by other studies such as Griffin and Lemmon (2002) and CHS (2008). ${ }^{3}$ While these papers analyze realized returns, there is also some evidence suggesting that expected returns increase in probability of default

\footnotetext{
${ }^{2}$ As an anecdotal check, we studied analyst reports on Ford Motors around late 2008 to early 2009. Clearly Ford was in deep financial distress at that time and the option to default was in-the-money. Yet there is no evidence that analysts from top investment banks incorporated that option value in their analysis. For example, Societe Generale based its price estimate on the long-term enterprise-value-to-sales ratio, while Deutsche Bank and JP Morgan used enterprise value over EBITDA ratio. In addition, Deutsche bank used a discount rate of $20 \%$, and Credit Suisse used a DCF model with "a big increase" in the discount rate. These different approaches result in very different values. For example, the JP Morgan target price for Ford in late October is $\$ 2.43$ per share, while the Credit Suisse target price is $\$ 1.00$ per share. It thus seems that even top equity analysts do not recognize the option-like features of distressed companies.

${ }^{3}$ The only exception is Vassalou and Xing (2004). Their findings are contested by CHS (2008). See also Da and Gao (2010) who show that the Vassalou and Xing results are due to short-term reversion and present only in the first month.
} 
(see, for example, Chava and Purnanandam (2010) using implied cost of capital).

There is also ample evidence that anomalies are more prevalent in distressed stocks. Griffin and Lemmon (2002) find that the value effect is stronger among distressed stocks. Avramov et al. (2007) report that momentum exists only amongst low credit rated firms. Avramov et al. (2010) present evidence that many anomalies such as price momentum, earnings momentum, credit risk, dispersion, idiosyncratic volatility, asset growth, capital investments, and value are concentrated among the worst rated stocks. Most of these studies suggest that these anomalies in distressed stocks are either the result of misvaluation or due to limits to arbitrage. We believe our paper is the first to systematically disentangle these two competing hypotheses and provide evidence in support of systematic valuation errors.

The rest of the paper is organized as follows. Section 2 introduces the distress measure and reports returns on distressed stocks. Evidence that anomalies are stronger in distressed stocks is also presented in this section. Section 3 presents our valuation model. We analyze the anomalies in distressed stocks further in Section 4 and show that these anomalies are located in the subset of misvalued distressed stocks. Robustness checks and discussion is in Section 5. Section 6 concludes.

\section{Financial Distress and Stock Returns}

\subsection{Data and distress measure}

There are a variety of measures of financial distress of companies. Altman (1968) and Ohlson (1980) are two popular approaches of predicting bankruptcy using accounting variables. Shumway (2001) estimates a dynamic model by adding equity market variables and Duffie, Saita, and Wang (2007) introduce the role of horizon in this forecasting exercise. CHS (2008) present a comprehensive analysis of bankruptcy prediction. They consider both accounting and equity market variables and account for different forecast horizons. Another alternative often used by practitioners is Moody's KMV model that relies on structural default model of Merton (1974). We use CHS measure as the primary measure of financial distress in our paper. Robustness exercises presented in Section 5.1.3 show the insensitivity of our results to which measure of distress we use. ${ }^{4}$

CHS use logit regressions to predict failure probabilities. We use their model for predicting bankruptcy over the next year (model with lag 12 in their Table IV) as our baseline

\footnotetext{
${ }^{4}$ Franzen, Rodgers, and Simin (2011) show that purely accounting measures of distress have become less accurate in recent times. Their objections do not apply to market-based measures.
} 
model. This model, which is repeated below, gives the probability of bankruptcy/failure from a logit model as:

$$
\begin{aligned}
C H S_{t}= & -9.16-20.26 \text { NIMTAAVG }+1.42 \text { TLMTA } A_{t}-7.13 \text { EXRETAVG } \\
& +1.41 \text { SIGMA }_{t}-0.045 \text { RSIZE }_{t}-2.13 \text { CASHMTA } A_{t}+0.075 \text { MB }_{t} \\
& -0.058 \text { PRICE }_{t},
\end{aligned}
$$

where NIMTA is the net income divided by the market value of total assets (the sum of market value of equity and book value of total liabilities), TLMTA is the book value of total liabilities divided by market value of total assets, EXRET is the log of the ratio of the gross returns on the firm's stock and on the S\&P500 index, SIGMA is the standard deviation of the firm's daily stock return over the past three months, $R S I Z E$ is ratio of the log of firm's equity market capitalization to that of the S\&P500 index, CASHMTA is the ratio of the firm's cash and short-term investments to the market value of total assets, $M B$ is the marketto-book ratio of the firm's equity, and PRICE is the log price per share. NIMTAAVG and EXRETAVG are moving averages of NIMTA and EXRET, respectively, constructed as (with $\left.\phi=2^{-\frac{1}{3}}\right)$ :

$$
\begin{aligned}
\text { NIMTAAVG } G_{t-1, t-12} & =\frac{1-\phi^{3}}{1-\phi^{12}}\left(\operatorname{NIMT} A_{t-1, t-3}+\ldots+\phi^{9} N I M T A_{t-10, t-12}\right), \\
\text { EXRETAVG } G_{t-1, t-12} & =\frac{1-\phi}{1-\phi^{12}}\left(\operatorname{EXRET}_{t-1}+\ldots+\phi^{11} \operatorname{EXXET}_{t-12}\right) .
\end{aligned}
$$

The source of accounting data is COMPUSTAT while all market level data are from CRSP. All accounting data are taken with a lag of three months for quarterly data and a lag of six months for annual data. All market data used in calculating the distress measure of equation (1) are the most current. We winsorize all inputs at the 5th and 95th percentiles of their pooled distributions across all firm-months, and PRICE is truncated above at $\$ 15$. Further details on the data construction are provided by CHS (2008) and we refer the interested reader to their paper. ${ }^{5}$ The sample period for our study is 1983 to 2009 as the coverage of quarterly COMPUSTAT data is sparse before this date.

Using this CHS measure, we sort all stocks into ten equal-sized portfolios. Decile one contains least distressed stocks while decile ten consists of most distressed stocks. The sorting

\footnotetext{
${ }^{5}$ There are two minor differences between CHS's approach and ours. First, CHS eliminate stocks with fewer than five nonzero daily observations during the last three months; and then replace missing SIGM A observations with the cross-sectional mean SIGMA in estimating their bankruptcy prediction regressions. We do not do make this adjustment. Second, CHS treat firms that fail as equivalent to delisted firms, even if CRSP continues to report returns for these firms. We do not make this adjustment either.
} 
is done at the end of each calendar quarter and we hold these portfolios for the subsequent quarter. ${ }^{6}$ Table 1 shows descriptive statistics on these deciles. We exclude observations in the top and the bottom percentiles in calculating the means and medians. In addition to size, market-to-book, market beta (calculated using last three years of data), we also report the percentage of firms reporting negative earnings, number of analysts, the standard deviation of their forecasts, and two proxies for liquidity, namely share turnover and Amihud's (2002) illiquidity measure. All analyst data are from IBES. For each characteristic, we first calculate the cross-sectional mean and median across stocks for each portfolio. The table then reports the time-series averages of these means and medians.

There is an inverse relationship between distress and firm size; size declines (monotonically based on medians) as one goes from D1 decile to D10 decile. Most distressed stocks are quite small with a median market capitalization of only $\$ 18$ million, which is an order of magnitude smaller than that of least distressed stocks (median market capitalization of $\$ 428$ million). Interestingly, though, there does not seem to be much of a pattern in average market-to-book ratios across distress-risk deciles. This suggests that, in spite of small size and higher riskiness, distressed stocks are accorded valuations in line with their less distressed counterparts.

Distressed stocks are riskier than other stocks. This is manifested both in measures of systematic risk (market beta) as well as total risk (volatility of returns). For instance, the average market beta of a stock in D10 decile is 1.37, well above one. The standard deviation of daily returns of D10 stocks is $7.4 \%$ (annualized 117\%), almost three times that of D1 stocks at 2.4\% (annualized 38\%). Distressed stocks are also less liquid. Although this is not evident in measures of share turnover, Amihud illiquidity is considerably higher for D10 stocks than for D1 stocks.

Partly reflecting their small size, average institutional ownership of most distressed stocks $(16 \%)$ is almost one-third that of least distressed stocks (47\%). Distressed stocks also have few analysts covering them. On average, there are only two analysts per D10 stock versus almost five per D1 stock. At the same time, there is wide dispersion of opinion about distressed stocks but relatively more homogeneity of opinion for least distressed stocks. The standard deviation of analysts' forecasts for earnings-per-share is 0.14 (0.04) for most (least) distressed stocks. Finally, a vast majority of distressed firms also report negative earnings in the calendar year prior to portfolio formation date. These facts about distressed stocks,

\footnotetext{
${ }^{6}$ Our baseline model uses a horizon of 12 months for bankruptcy prediction even though the portfolio holding period is only three months. CHS (2008) argue that a firm's equity return is the most powerful predictor of bankruptcy over short horizons but this is not very useful "just as it would not be useful to predict a heart attack by observing a person dropping to the floor clutching his chest."
} 
although not unsurprising, do suggest that distressed stocks are quite atypical.

\subsection{Stock returns}

We start our analysis by revisiting the relation between distress and stock returns. We compute value-weighted monthly returns for distress-risk sorted deciles and report statistics of these returns in Table 2. In addition to reporting the average return in excess of the riskfree rate, we also report the alphas from one-, three-, and four-factor models. The one-factor model is the CAPM model. We use Fama and French (1993) factors in the three-factor model. These factors are augmented with a momentum factor in the four-factor model. All factor returns are downloaded from Ken French's website. All returns and alphas are in percent per month and numbers in parentheses denote the corresponding $t$-statistics. ${ }^{7}$

Distress is inversely related to subsequent stock returns. Average stock returns of the least distressed stocks $(0.82 \%)$ are statistically significantly different from those of the most distressed stocks $(-0.62 \%)$. The difference in returns at $1.44 \%$ is economically large and statistically significant. Decile D10 also has higher market beta (1.68) than that of decile D1 (0.86) (not reported in the table). This means that the CAPM alpha of the long-short D1-D10 portfolio (1.90\%) is higher than the difference in excess returns.

Since stocks in D10 decile are much smaller than those in D1 decile (Table 1), the SMB factor loading of the long-short D1-D10 portfolio is large (1.54). However, the size premium is small during our sample period; average return to SMB factor is only $0.09 \%$ per month. The net result is that the addition of size and value factors does not change much the magnitude of alphas; three-factor alphas are similar to CAPM alphas. The addition of momentum factor shows interesting patterns. The magnitude of four-factor alphas is lower than that of three-factor alphas. This suggests that least distressed stocks perform well while the most distressed stocks perform poorly over the holding period (the UMD factor loading of the long-short D1-D10 portfolio is 0.92). Recall that one of the ingredients of our distress-risk CHS measure is stock returns measured prior to the portfolio formation date. Since distressed stocks have typically negative past returns, part of their poor subsequent performance is explained by the mechanical effects of momentum. This explains why four-factor alphas are lower than three-factor alphas. However, momentum is unable to com-

\footnotetext{
${ }^{7}$ Whenever available from CRSP, we add delisting return to the last month traded return. If the delisting return is not available, we use the last full month return from CRSP. This could, in principle, impart an upward bias to portfolios returns (Shumway (1997)). However, CHS (2008) note, and we confirm, that this has no material impact on our results. Note that our procedure implies that the proceeds from sales of delisted stocks are reinvested in each portfolio in proportion to the weights of the remaining stocks in the portfolio.
} 
pletely account for the excess returns; the four-factor alpha at $1.12 \%$ is strongly statistically significant. Our results are comparable to those in the extant literature. For example, CHS (2008) report three- and four-factor annualized alphas of $22.65 \%$ and $12.07 \%$, respectively.

\subsubsection{Anomalies}

We next turn to analysis of double-sorted portfolios. The three main anomalies that we analyze in this paper are the size-premium, value-premium, and momentum-premium. Accordingly, we use value-weighted portfolios sorted independently on distress risk and these characteristics. In order to have reasonably populated portfolios, we sort stocks into quintiles for each sorting variable. We sort at the end of each calendar quarter and hold these 25 $(5 \times 5)$ portfolios for the next quarter for the analysis of size- and value-premium. Given the widely documented evidence that the momentum stragetgy is most profitable for a sorting period of six months and a holding period of six months with a gap of one month, we follow this in our analysis of momentum strategy. We, therefore, sort at the end of each month (based on six-month returns by skipping the most recent month) and hold these 25 portfolios for the next six-months for the analysis of momentum-premium (the resulting overlapping portfolios are equally-weighted).

Table 3 reports the average excess return (in excess of the risk-free rate) and the CAPM alphas of these portfolios. To conserve space, we do not report three- or four-factor alphas as our intention is to demonstrate the well-known departures from CAPM. These alternative alphas, which are available upon request, follow the pattern expected from these alternative factor models (for example, smaller three-factor alphas for size sorted and book-to-market sorted stocks, and smaller four-factor alphas for past return sorted stocks).

Panel A of Table 3 shows the results of size and distress-risk sorted portfolios. The relation between distress risk and stock returns is not explained by size; CAPM alphas of long-short D1-D5 portfolios are economically large and statistically significant for both small $(1.50 \%)$ and large $(1.19 \%)$ stocks. Small stock returns are also higher than big stock returns in all distress-risk quintiles. The size premium alphas are in the range of $0.55 \%$ to $0.90 \%$ and statistically significant, except for the D5 quintile. We also find that there is bigger variation in market betas across distress-risk quintiles than across size quintiles (not reported in the table). This implies that the stock returns of corner portfolios show interesting patterns. In particular, small least-distressed stocks (top left corner) have the highest alpha (1.08\%) and the smallest market beta (0.72) while large most-distressed stocks (bottom right corner) have the most negative alpha $(-0.97 \%)$ and second-largest beta (1.65).

The value anomaly is analyzed in Panel B of Table 3. The D1-D5 portfolio alphas are 
again large for all categories of stocks sorted by market-to-book. There is some evidence that the distress-risk premium is stronger in growth stocks (CAPM alpha of 2.03\%) than that for value stocks (CAPM alpha of 1.50\%). The value premium is also evident in all distress-risk category stocks and, for our immediate purpose, stronger in most distressed stocks (CAPM alpha of $0.77 \%$ ) than in least distressed stocks (CAPM alpha of $0.24 \%$ ). Consistent with Griffin and Lemmon (2002), we also find that alphas are the most negative $(-1.81 \%)$ for growth stocks in the most distressed category.

Finally, Panel C of Table 3 presents results for the relation between momentum and distress-risk. Least distressed stocks have higher returns than most distressed stocks but the difference declines monotonically as one goes from loser stocks (CAPM alpha of 1.90\%) to winner stocks (CAPM alpha of $0.46 \%$ ). Thus, the distress-risk premium is strong in loser stocks but statistically insignificant for winner stocks. Conversely, we find that returns to the winners-losers portfolio increase monotonically as one goes from least distressed to most distressed stocks. Momentum anomaly is non-existent in least distressed stocks (CAPM alpha of $-0.13 \%$ ) but strong in most distressed stocks (CAPM alpha of $1.31 \%$ ). The latter is consistent with Avramov et al. (2007) who show that momentum exists only in low credit-rating firms.

To summarize, consistent with prior literature, we find that distress risk is inversely related to stock returns and that many of the anomalies are more pronounced in more distressed stocks than they are in less distressed stocks.

\section{Valuation model}

Results in the previous section reiterate two basic facts. One, distressed stocks are atypical (more volatile and less 'well-known' than solvent stocks). Second, stock return anomalies are more pronounced in distressed stocks. We argue that these two facts can be reconciled by recognizing that distressed stocks are difficult to value. Most of the distressed companies have had negative earnings in the past (Table 1) implying the unsuitability of the popular random-walk model of earnings forecast (see Ball and Watts (1972) and Foster (1977)). Standard valuation techniques such as multiples-valuation or DCF are, therefore, not wellsuited for distressed companies.

A key characteristic of distressed firms is their option to default. Any valuation model that ignores the value of this option is going to produce values that are further away from fundamental value than a model that explicitly accounts for this option. We, accordingly, use an option pricing model that recognizes the option-like nature of distressed equities. Option 
pricing or structural models have been employed in the literature to gauge the probability of default and to value corporate bonds given the value the equity (see, for example, Merton (1974), Geske (1978), and Geske and Delianedis (2003), among others). Our objective is to deploy an option pricing model to perform valuation of equity itself of distressed companies.

\subsection{Model}

We assume that the cash flows of the firm are driven by a variable $x$ that reflects stochastic demand for the firm's products. The firm incurs fixed costs and uses debt and, therefore, has contractual obligations to make coupon and principle payments to its debtholders. We also assume that a firm with negative free cash flow incurs an additional proportional expense $\eta$. This extra cost reflects additional expenses that a financially distressed firm has to incur in order to maintain healthy relationship with suppliers, retain its customer base, deal with intensified agency costs like the underinvestment problem, or the additional costs of raising new funds to cover for the short fall in cash flows. The free cash flow to equityholders is then given by:

$$
C F_{t}=\left(x_{t}-C_{t}-F\right)\left(1-\tau+\eta 1_{x-C-F<0}\right)
$$

where $x$ is the state variable, $C_{t}$ is the total contractual payments to debtholders due at time $t$ (interest payments as well as repayment of principal), $F$ is the total fixed cost that the company incurs per unit of time, $\tau$ is the tax rate, and $1_{\{\cdot\}}$ is an indicator variable. We further assume that $x$ follows a geometric Brownian motion under the physical measure with a drift parameter $\mu_{P}$ and volatility $\sigma$ :

$$
\frac{d x_{t}}{x_{t}}=\mu_{P} d t+\sigma d W_{t}
$$

Default is endogenous in our model (similar to the majority of structural models). The equity holders are endowed with an option to default which they exercise optimally; they default if the value of equity is zero and continuing to operate the firm results in a negative value. ${ }^{8}$ The value, $V_{0}$, of equity (given the intial state variable $x_{0}$ ) is equal to the expected present value of future cash flows under the risk-neutral measure discounted by the risk-free rate $r$ :

$$
V_{0}\left(x_{0}\right)=\sup _{T_{x_{d}}(t)} \mathbf{E}_{x_{0}}^{Q} \int_{0}^{T_{x_{d}}(t)} e^{-r t} C F_{t} d t,
$$

where $x_{d}(t)$ is the optimal default boundary and $T_{x_{d}}(t)$ is a first-passage time of the process

\footnotetext{
${ }^{8}$ Note that the equity holders of a firm with negative free cash flow may continue to inject cash into the firm (unless they decide to default), but it is costly do so and this cost is reflected in the parameter $\eta$.
} 
$x$ to the boundary $x_{d}(t)$. The default boundary is a function of time because debt has final maturity and coupon and principal payments are allowed to vary over time. Note that in our model even a zero-debt firm will find it optimal to shut down operations if fixed costs $F$ are high enough and the cash flows falls below a certain negative threshold.

Equation (5) shows two fundamental differences between our valuation approach and traditional DCF analysis. First, we discount cash flows to equity holders only up until the stopping time $T_{x_{d}}(t)$. This stopping time is determined as the outcome of the optimization problem of the equity holders and results from the optimal exercise of the option to default. By contrast, the DCF method implicitly assumes an infinite discounting horizon and ignores that option. Second, we use the risk-free rate and discount payouts to shareholders under the risk-neutral measure, while the DCF performs discounting under the physical measure and uses a constant discount rate. This also distorts valuations because risk and the appropriate discount rate under the physical measure vary significantly as the firm moves in and out of financial distress. In other words, as is well-known, one cannot price an option by expectation under the physical measure.

\subsection{Implementation}

We use both annual and quarterly Compustat data items as inputs to the model. Structural models typically use either earnings or the unlevered firm value as a state variable that drives valuation. ${ }^{9}$ While both cash flows and earnings seem reasonable candidates, these pose implementation issues. Earnings is an accounting variable which may not be directly related to valuation. Cash flow data, on the other hand, is often missing from quarterly Compustat data making it difficult to compute cash flow volatility. Furthermore, cash flows are subject to one-time items such as lump-sum investments, and therefore the current value of cash flows may not necessarily be representative of its evolution in the future. To smooth out these potential short-term variations in cash flows, we use gross margin (defined as sales less costs of goods sold) minus capital expenditures as a proxy for the state variable $x$. Hence, our state variable is defined as:

$$
x_{i, t}=\text { Sales }_{i, t}-\text { COGS }_{i, t}-\text { Capex }_{i, t},
$$

where Sales is the annual sales, COGS is the cost of goods sold, Capex is the capital expenditures. There is a lot of short-term variation in capital expenditures. In order to reduce this noise, we compute the average Capex/Sales ratio for 3-digit SIC industry over

\footnotetext{
${ }^{9}$ However, see Goldstein, Ju, and Leland (2001) for a criticism of the use of unlevered firm value.
} 
the last tree years, $\overline{C S R}_{t}$, and use this ratio and current sales for firm $i$ to proxy for firm $i$ capital expenditures:

$$
\text { Capex }_{i, t}=\text { Sales }_{i, t} \times \overline{C S R}_{t} .
$$

We use selling, general, and administrative expenses (compustat item $X G N A$ ) as a proxy for the fixed costs, $F$. We use Compustat annual items $D L T$ (long-term debt) and $D L C C$ (debt in current liabilities) as proxies for company's long and short-term debt. We further assume that the short-term debt matures in one year, while the long-term debt matures in five years and pays an $8 \%$ annual coupon. This yield is consistent with the return on high-yield exchange traded bond funds. In this case $C$ equals the total interest payment due in a given year plus the repayment of principal one and five years in the future. We use $35 \%$ for the corporate tax rate, $\tau$, while we set the distress costs, $\eta$, to $10 \%{ }^{10}$

To model the growth rate of $x$ under the physical measure we use the standard approach discussed in many corporate finance textbooks (see, for example, Brealey, Myers, and Allen (2011)) and argue that:

$$
\mu_{P}=R R \times R_{A}=(1-P R) \times R_{A},
$$

where $R R$ is the retention ratio, $P R$ is the payout ratio, and $R_{A}$ is the return on assets, or the weighted average of the cost of equity capital and return on debt. We estimate the cost of equity by using the CAPM and estimating firms' betas over the past three-year period and then averaging across all firms in the same 3-digit SIC industry. We further assume the cost of debt of $8 \%$. To make the model more realistic we assume that a financially distressed firm does not pay any dividends over a five year period. After this period, the payout ratio increases to $15 \%$ (unless the firm has defaulted before). The drift of $x$ is then given by $\mu_{P}=R_{A}-D Y_{P}$, while the growth rate under risk-neutral measure is given by $\mu_{Q}=r-D Y_{Q}$, where $D Y$ is the dividend yield and $r$ is the risk-free rate. Since the dividend yield is the same under both measures, $D Y_{P}=D Y_{Q}$, it follows that:

$$
\mu_{Q}=r-R_{A}+\mu_{P}=r-P R \times R_{A} .
$$

We proxy $\sigma$ by the annualized quarterly volatility of sales over the last eight quarters. If quarterly sales values are not available in Compustat, we use the average quarterly volatility of sales of the firms in the same 3-digit SIC industry over the last eight-quarter period. We use volatility of sales as opposed to volatility of $x_{i, t}$ in (6) because we believe it better reflects

\footnotetext{
${ }^{10}$ Weiss (1990) estimates the direct costs of financial distress to be of the order of $3 \%$ of firm value, Andrade and Kaplan (1998) provide estimates between 10\% and 23\%, while Elkamhi, Ericsson, and Parsons (2011) use the value of $16.5 \%$ in their analysis. Our valuation results are not significantly affected by reasonable variations in the value of the distress cost parameter and the coupon yield.
} 
the volatility of the underlying demand-driven stochastic process, which drive valuation in structural models like ours. Using volatility of $x_{i, t}$ instead would capture some short-term variations in the costs of goods sold and capital expenditures which are not related to the underlying economic uncertainty and therefore should not affect the value of the option to default. ${ }^{11}$

A potential problem with our approach is that some distressed companies have negative current values of $x$. Since we cannot assume geometric growth for such companies, we assume, instead, that $x$ follows an arithmetic Brownian motion until the moment when it reaches the value equal to its annualized standard deviation (of course, before the company defaults), at which point we assume that $x$ begins to grow geometrically. Finally, we employ a standard binomial numerical algorithm to determine both the optimal default boundary and the value of equity in equation (5). Further numerical details on the implementation of our procedure are provided in Appendix A.

Table 4 provides summary statistics on the inputs to our model. Wherever possible, we contrast these statistics with those for the least distressed firms (not reported in the table). The average capital expenditure to sales ratio for distressed stocks is $8.4 \%$, which is not significantly different from that least distressed firms (7.3\%). However, distressed firms exhibit very high volatility of sales; the average annualized volatility of sales during our sample is $67 \%$ (versus $31 \%$ for least distressed firms). Perhaps unsurprisingly, the distressed firms have fairly high leverage (average short-term plus long-term debt as a fraction of the sum of the short and long term debt and common equity is $37 \%$, which is much higher than that of a typical firm (10\%) over this sample period. At the same time, fixed costs are very high for our firms averaging $49 \%$ of sales, which is more than twice that of least distressed firms $(23 \%)$. This highlights the fact that our model is a model of both economic and financial distress. A zero-leverage firm can continue operating for some time with negative cash flows but the equity holders have the option to optimally exit ('default') - this option value is accounted for by our model. Finally, consistent with the evidence in Table 1, distressed firms have negative gross margin, on average. The median gross margin is, however, positive at $27 \%$. We, thus, use the geometric version of our model for the majority of distressed stocks.

\footnotetext{
${ }^{11}$ We get similar results using volatility of Sales $_{i, t}-$ COGS $_{i, t}-$ Capex $_{i, t}$.
} 


\section{Stock Returns of Distressed Firms}

We restrict our attention to the most distressed stocks in this section. As before, we sort all stocks into five quintiles (least distressed, D1, to most distressed, D5) based on CHS distress-risk measure using current market data and quarterly accounting data of the previous quarter. The sorting is done at the end of each calendar quarter and the portfolios are held for the subsequent quarter. We further sort all stock in the D5 quintile into five equal-sized portfolios according to the ratio of the equity value implied by our model and actual equity value. These portfolios are labeled R1 (most overvalued) to R5 (most undervalued). Stocks for which we cannot compute a model implied value are placed in another portfolio entitled 'No value.' We report characteristics on all these portfolios in Table 5. In addition to returns and factor model alphas, we also report average firm size, market-to-book ratio, and past six-month returns on stocks in these portfolios. In this and all future tables, we report returns to only the most distressed stocks in the D5 quintile.

We are unable to calculate model value for 63,160 firm-months. This represents almost $21 \%$ of the entire sample of most distressed stocks. The primary reason we cannot do so is missing quarterly sales data in Compustat, making it impossible to compute volatility. Stocks in R1 quintile have, unsurprisingly, very high market-to-book ratios. Interestingly, firm size declines as one goes from R1 to R5 suggesting that investors have more optimistic expectations for bigger firms than those for smaller firms. Another reason for more optimistic expectations might be overreaction (Lakonishok, Shleifer, and Vishny (1994)) to past performance; average past returns for R1 (9.32\%) are higher than those for R5 (-4.26\%). We also report equity issuance (in percent), measured by the difference between the sale and purchase of common and preferred stock during the year, scaled by equity market value at the beginning of the year. Stocks in R1 quintile issue more equity (11.5\%) than stocks in R5 quintile $(5.6 \%)$. These patterns are consistent with our valuation model under the additional assumption that managers of these firms understand true valuations and time the market in issuing equity. ${ }^{12}$

Portfolio returns for all the five R1 to R5 quintiles show unambiguous patterns consistent with our valuation model. For instance, the excess return for R1 quintile is $-1.16 \%$ while that for R5 quintile is close to zero. Although the decline in returns is not monotonic, the long-short R5-R1 portfolio returns are $1.13 \%$ and statistically significant. These differences are not explained by factors as factor model alphas are economically large and, for the large

\footnotetext{
${ }^{12}$ Park (2011) finds that distressed firms issue more equity than non-distressed firms, and the low returns of distressed firms are only found in firms that issue the most equity.
} 
part, statistically significant (the exception is three-factor alpha). ${ }^{13}$

We would like to emphasize that our valuation model does a good job of relative valuation by separating under- and overvalued stocks amongst the subset of distressed securities. At the same time, though, the average returns across R1 to R5 quintiles (and the 'No value' portfolio) are still negative. Moreover, the average returns of stocks classified as fairly valued by our model (in other words, stocks for which market value is close to our model implied value; numbers not reported in the table) are also negative. This implies that our valuation model still misses common factors that could explain the overall low/negative returns of distressed stocks. We, therefore, urge caution in using our model as an absolute valuation model and prefer to use it as a means of relative valuation. Finally, we reiterate that the power of our model is in the valuation of the option to default. For stocks far from the boundary of default, normal valuation techniques such as discounted cashflow could still be adequate and not much may be gained by using our model for such stocks.

\subsection{Anomalies in Distressed Stocks}

Our main interest is in analyzing stock return anomalies in distressed stocks. We have documented in Section 2.2.1 that anomalies are most pronounced in distressed stocks. Our main conjecture is that anomalies are driven by the investors' inability to correctly value distress stocks. Less distressed stocks have more predictable cash flows and standard techniques are amenable to fundamental valuation. This coupled with the facts that there are many analysts covering these stocks and that these stocks have high institutional ownership implies that scope for systematic mispricing, viz. anomalies, is low. On the other hand, distress stocks have option-like features. The resulting valuation difficulties means that anomalies are more widespread in distressed stocks. Our valuation model of Section 3 separates fairly valued versus misvalued distressed stocks. We expect that, within the subset of distressed stocks, anomalies are stronger in stocks that are most misvalued.

To verify our conjecture, we revisit anomalies in distressed stocks controlling for their relative valuation. Since our conjecture is more directly related to misvaluation rather than under- or overvaluation, we classify stocks as fairly valued and misvalued, in contrast to the previous section where we considered under- and overvalued stocks separately.

The exact procedure is as follows. We sort all stocks into five quintiles (least distressed, D1, to most distressed, D5) based on distress-risk $C H S$ measure using current market data

\footnotetext{
${ }^{13}$ Next quarter returns for stocks which we cannot value are also quite negative. Their excess return $(-0.42 \%)$ and four-factor alpha $(-0.84 \%)$ are similar to those of quintile R2. This provides circumstantial evidence that the stocks excluded from our analysis are closer to being overvalued rather than undervalued.
} 
and quarterly accounting data of the previous quarter. We further double-sort all stocks in the D5 quintile based on two variables. The first sorting variable is value gap, defined as the absolute value of the log of the ratio of the equity value implied by our valuation model and the actual equity value (stocks for which we cannot compute a model value are excluded from this analysis). We label these portfolios VG1 to VG3; VG1 has the least value gap (most fairly valued stocks) while VG3 has the highest value gap (most misvalued stocks). The second sorting variable is a stock characteristic. We use market capitalization, market-to-book ratio, and past six-month returns in turn for the second sorting variable. The double-sorting is done independently into terciles to obtain a total of nine portfolios. We use terciles rather than quintiles to have well-populated portfolios. As before, sorting is done at the end of each calendar quarter and we hold these portfolios for one subsequent quarter for size- and value-premium; sorting is done at the end of each month and the holding period is next six-months for momentum.

Table 6 reports the excess returns and CAPM alphas to these triple-sorted portfolios. We report returns only for the nine portfolios of the most distressed quintile. We also report returns for the long-short VG1-VG3 tercile. Since VG3 includes both under- and overvalued stocks, these long-short returns are hard to interpret but are provided for completeness sake. The portfolios of the most interest to us are the long-short portfolios sorted on firm characteristic for each value-gap tercile (the last row in each panel).

Panel A considers firm size as the stock characteristic sorting variable. The difference between returns to small and big firms increases monotonically from $0.66 \%$ for VG1 tercile to $1.29 \%$ for VG3 tercile. Alphas show a similar pattern and are slightly higher in magnitude than excess returns. It is worth noting that small fairly valued stocks (top left corner portfolio) have alphas that are fairly close to zero. However, big stocks have large and negative alphas in all value-gap categories. This means that most of the returns to this anomaly are due to the underperformance of big stocks. It is of interest to examine further the source of large negative alphas for big stocks. Even though these alphas are uniformly large for big stocks, our valuation model implies that the magnitude of alphas is bigger for overvalued stocks than that for undervalued stocks. This is precisely what we find in unreported results. CAPM alpha for big overvalued stocks is $-1.76 \%$ but only $-0.25 \%$ for big undervalued stocks suggesting that a large part of the underperformance of big VG3 stocks is accounted for by big overvalued stocks.

The value anomaly in distressed stocks is explored in Panel B. Across value gap terciles, there is very little difference in returns to value stocks (CAPM alpha of $-0.01 \%$ ) but economically and statistically large difference to growth stocks (CAPM alpha of -1.35\%). Focusing on the difference between value and growth stock returns across value gap ter- 
ciles, we find, once again, that value-growth portfolio return increases monotonically from $-0.19 \%$ for VG1 tercile to $1.29 \%$ for VG3 tercile; the pattern is replicated in CAPM alphas. We also find that growth stocks in VG3 tercile have the most negative alpha $(-2.58 \%)$. In unreported results, we find that this under-performance of growth stocks is most pronounced in overvalued stocks and less so in undervalued stocks. These facts highlight that our valuation model, that accounts for option value, does a good job of separating fairly-valued and misvalued stocks in the category of growth stocks, presumably stocks that are the most difficult to value.

Finally, we analyze momentum in Panel C. Here we find that, across value gap terciles, there is a bigger difference in returns to loser stocks (CAPM alpha of -1.08\%) than those of winner stocks (CAPM alpha of -0.50\%). Looking at the winner-loser portfolio, we find that the momentum anomaly is also stronger in misvalued stocks than it is in fairly valued stocks. The winner-loser portfolio alphas are $1.06 \%$ for VG3 tercile but only $0.48 \%$ for the VG1 tercile. And once again, there is evidence, not reported in tables, that momentum profits are higher in overvalued stocks (CAPM alpha of 1.25\%) than in undervalued stocks (CAPM alpha of $0.88 \%$ ), although both are economically large and statistically significant.

Figure 1 illustrates the performance, measured by cumulative CAPM alpha, over time of the firm's characteristics long-short portfolios within the VG1 to VG3 terciles. The size and value effects show clear patterns from the very early years consistent with our conjecture; both effects are strongest amongst the VG3 firms and weakest amongst the VG1 firms. The cumulative momentum effect seems similar across the VG terciles for a longer period, until 1999; from that point it exhibits a clear separation, where momentum is significantly weaker for VG1 firms than that for VG2 and VG3 firms.

To summarize, in this subsection, we refine the analysis presented in Section 2.2.1. We show that not only are the anomalies pronounced in distress stocks but within the subgroup of distressed stocks, these anomalies are the strongest in misvalued stocks (with some evidence that they are even stronger in overvalued stocks than in undervalued stocks). The evidence thus lends credence to our belief that these anomalies are related to investors' inability to properly value these stocks and, in particular, to not account for the value of the option to default by the distressed stocks.

\section{Robustness and discussion}

In this section, we first conduct robustness checks and then discuss alternative explanations for our results. 


\subsection{Robustness checks}

\subsubsection{Subsamples}

We start by analyzing the robustness of our results in various subsamples. We consider three different kinds of subsamples. The first simply tabulates results for the months of January versus the rest of the months. The second considers different states of the economy. We use NBER recession dummy as an indicator of the health of the economy for this exercise. Third, we consider calendar patterns in our results by separately tabulating the results for the decades of 1980s, 1990s, and 2000s. ${ }^{14}$ To reduce the clutter in the tables, we report only the excess returns and CAPM alphas for long-short portfolios sorted on firm characteristics for the three value gap terciles. The results of this exercise are reported in Table 7. To facilitate comparison with the previous results, we also report the full-sample results in the first row of each panel.

Panel A shows that the size effect is strong in January but non-existent in other months, consistent with the prior literature. However, even within the months of January, size effect is stronger in VG3 tercile (CAPM alpha of 10.25\%) than that in VG1 tercile (CAPM alpha of $6.16 \%$ ). The average returns to the long-short portfolio are higher during expansions than during recessions. In fact, there is no economically or statistically significant size effect in VG1 and VG2 terciles during recessions. For our interest, though, the size effect is the strongest in VG3 tercile in all states of the economy. Finally, calendar patterns reveal that, consistent with other documented evidence (see, for example, Fama and French (1992)), the size effect was weak in the 1980s but made a strong comeback in the 1990s and is also strong in the first decade of this century. Even in the 1980s, however, the size effect is again the strongest in VG3 tercile.

Panel B for the value effect echoes many of the results on Panel A; value effect does not exist for January for VG1 tercile but is strongest in January for VG3 tercile. The January effect for value/growth stocks is consistent with Hawawini and Keim (1999). There is also some weak evidence that value effect is stronger in recessions than in expansions (average long-short portfolio return across the three terciles is $1.58 \%$ in recessions but only $0.87 \%$ in expansions). However, the difference in the long-short portfolio return between the VG3 and the VG1 tercile is roughly the same in both recessions $(1.49-0.85=1.42 \%)$ and expansions $(1.26-(-0.33)=1.51 \%)$. Finally, the value effect is strong in VG3 tercile in the 1980s and 1990s but weak, and statistically insignificant, in the 2000s.

Finally, Panel C analyzes the momentum effect in subsamples. Jegadeesh and Titman

\footnotetext{
${ }^{14}$ Chava and Purnanandam (2010) argue that underperformance of high default risk stocks is due to surprisingly low realized returns only during the 1980s.
} 
(1993) show that momentum returns are negative during January and we replicate that

finding for our sample and show that most of these negative returns are concentrated in the VG3 tercile. Asness, Moskowitz, and Pedersen (2009) report a business cycle component to momentum returns. We also find that momentum returns are stronger in expansions than during recessions. However, they are stronger for VG3 tercile than for VG1 tercile in all states of the economy. The calendar patterns reveal, though, that difference in momentum returns across the value gap terciles is present only during 2000s.

In sum, our earlier results on the relative strength of anomalies in various value gap terciles of distressed stocks are robust across various subsamples, with occasional exceptions.

\subsubsection{Different horizons}

Our results are based on a holding period of three months. Avramov et al. $(2009,2010)$ show that most of the credit risk effect prevails around credit rating downgrades. However, CHS (2008) do not find that distressed stocks do particularly poorly around earnings announcements. In this section, we simply look at the horizon effects in our results. Specifically, we consider holding periods of six, 12, and 18 months. This implies that we have overlapping portfolios. We take equal-weighted average of these overlapping portfolios similar to the approach of Jegadeesh and Titman (1993). Since the holding period is six months for momentum anomaly in our main results, we consider holding periods of only 12 and 18 months for this anomaly in this section.

Table 8 reports the results of this exercise. As before, we report only the excess returns and CAPM alphas for long-short portfolios sorted on firm characteristics for the three value gap terciles. Panel A shows that the size anomaly is robust across longer horizons. CAPM alpha for the small-big portfolio declines slightly from $1.74 \%$ for three-months to $1.45 \%$ for six-months and $1.22 \%$ for one-year holding period. For each horizon, however, the excess returns and the CAPM alpha are larger for VG3 tercile than those for VG1 tercile.

Panel B shows very similar results for value anomaly. Here the decline in excess returns/ alphas is economically less significant for longer horizons. For example, the CAPM alpha for the value-growth portfolio for horizons of three, six, 12, and 18 months is $1.24 \%, 1.23 \%$, $1.03 \%$, and $1.09 \%$ respectively. In each case, again, the returns are higher for VG3 tercile than those for VG1 tercile.

Panel C shows that momentum strategy weakens considerably at longer horizons, as expected. For instance, the CAPM alpha for winner-loser portfolio halves from $1.06 \%$ for six-month horizon to only $0.52 \%$ for 12 -month horizon and economically insignificant $0.13 \%$ for 18-month horizon. In each case, however, the magnitude is still higher for VG3 tercile 
than that for VG1 tercile. We conclude that our results are robust to different horizons.

\subsubsection{Different distress measures}

We now explore whether our results are sensitive to the distress measure that we use in the paper. We use three additional distress measures. The first is the standard KMV measure calculated using quarterly data on short- and long-term liabilities. We classify firms KMV's probability of bankruptcy higher than 0.25 as distressed firms. The second is credit rating based on S\&P long-term bond rating. Data on these ratings are available only from 1987 onwards and we classify all firms with a rating of $\mathrm{BB}+$ and lower as distressed firms. The third measure of distress is Altman (1968) Z-score calculated using quarterly accounting data. All firms with a Z-score of lower than 1.81 are classified as distressed firms, as suggested by Altman. ${ }^{15}$

Using these distress measures, we follow the same procedure for double-sorting the distressed stocks as before. Table 9 reports the excess returns and CAPM alphas for long-short portfolios sorted on firm characteristics for the three value gap terciles. The first row of each panel shows the results using the $C H S$ measure to facilitate comparison.

Panels A and B show that the size-effect and the value-effect is strongest for VG3 tercile regardless of which measure we use. At the same time, the absolute magnitude of longshort portfolio returns varies depending on the distress measure. In fact, the returns are, in general, highest for the $C H S$ measure. This underscores the efficacy of the $C H S$ measure (using accounting and market data) to best identify distressed firms. For our goal in this section of documenting robustness of our results to various risk measures though, this has no material effect. Panel $\mathrm{C}$ shows again that the momentum returns are highest for VG3 tercile for all distress measures. The biggest difference between VG3 and VG1 tercile is, however, obtained for credit rating based distress measure. We conclude that our results are robust to different measures of distress.

\subsection{Discussion}

Arbitrage risk has been frequently suggested in the literature to explain anomalies (Shleifer and Vishny (1997)). The idea is that trading impediments, such as short selling, limited

\footnotetext{
${ }^{15}$ We explored variations on these measures as well. For example, we check our results for (i) KMV measure calculated using annual data for liabilities, (ii) KMV measure that adds the present value of fixed costs (measured by SG\&A divided by 0.1) to total liabilities (intended to capture operating leverage), (iii) Z-score using annual accounting data, and (iv) Z-score where all financial ratios are winsorized at the 5th and the 95th percentile (as in CHS (2008)). The results of all these exercises are very similar to those reported in the paper.
} 
capital, and/or poor liquidity prevent arbitrageurs from exploiting the anomalous return patterns. Empirical evidence on the limits to arbitrage is mixed. For example, Doukas, Kim, and Pantzalis (2010) find that arbitrage risk is positively related to mispricing, while Brav, Heaton, and Li (2010) reject this argument for both under- and over-valuation anomalies.

We believe that arbitrage risk is not enough to explain our results. It is true that distressed stocks are small, illiquid, have low institutional ownership, fewer analyst coverage, and higher beta and idiosyncratic risk (Table 1), all proxies for higher arbitrage risk. However, we have reported in this paper that anomalies are located only in a subset of distressed stocks, namely the misvalued stocks. The real test of the limits of arbitrage argument is, therefore, whether there are cross-sectional differences, vis-à-vis arbitrage risk proxies, between different groups of distressed stocks.

We explore this issue further in this section. We sort all stocks into five quintiles (least distressed, D1, to most distressed, D5) based on CHS (2008) distress-risk measure using current market data and quarterly accounting data of the previous quarter. All stocks in the D5 quintile (most distressed firms) are further sorted into five equal-sized portfolios based on our valuation model. The second sorting is done based on the value gap.

Table 10 reports the characteristics of these portfolios. The table shows the mean and median for a set of variables. Both VG1 and VG5 stocks are illiquid but there is no appreciable difference in illiquidity across these groups of stocks (VG5 stocks have higher mean, but lower median Amihud illiquidity). There is also no economically or statistically significant difference in standard deviation of returns, institutional ownership, or number of analysts across stocks sorted by value gap. For example, institutional ownership is $19 \%$ and standard deviation of returns is 6.5\%-7.0\% for both VG1 and VG5 quintiles. Thus common proxies of arbitrage risk do not suggest any differences between fairly valued and misvalued stocks.

There are, however, other characteristics of stocks in VG1 and VG5 quintile that are suggestive of return differences across these stocks, viz. anomalies. First, although the proportion of distressed firms reporting negative earnings is very high, there are still more firms reporting negative earnings amongst misvalued stocks $(86.3 \%)$ than those amongst more fairly valued stocks (80.6\%). Second, the standard deviation of analysts' forecasts is higher for VG5 stocks $(16.0 \%)$ than that for VG1 stocks (10.1\%). This suggests that investors face additional difficulty in valuing stocks which report more negative earnings and the opinion on these stocks shows more divergence. Evidently, the latter category of stocks show more misvaluation and, as documented in this paper, more return anomalies.

We hasten to add, though, that we only claim that these characteristics are correlated with more misvaluation. The question of why these characteristics might lead to misvaluation 
is outside the scope of our study. More pertinent to our purpose is that we find little evidence to support the limits to arbitrage argument but more suggestive evidence to support misvaluation story.

\section{Conclusion}

We propose an explanation for why return anomalies are concentrated among financially distressed stocks. We posit that distressed stocks are inherently hard to value and have characteristics that render standard valuation techniques like DCF or valuation by multiples inappropriate. In particular, the majority of distressed stocks have negative earnings, and extremely volatile sales and cash flows. Furthermore, these firms have low analyst coverage and high dispersion of analyst forecasts.

On the other hand, distressed equities are embedded with a default option giving rise to a striking similarity between equity value and the value of a financial call option. We believe that a meaningful valuation model should take this optionality into account. We build such a model by explicitly accounting for the value of the option to default and show that our model does a good job separating over- and undervalued stocks.

We deploy our model to further classify stocks into reasonably priced versus mispriced based on their relative valuation (market value versus our valuation measure). If anomalies are driven by investors' inability to value distressed stocks correctly, we expect anomalies to be stronger amongst most misvalued stocks. The results support our conjecture. We find that size, value, and momentum anomalies are all concentrated among most misvalued stocks (as classified by our model). The results are robust to various subsamples, return horizons, and alternative distress measures. We also find that difficulty to arbitrage alone

cannot account for our findings. Overall, our evidence suggests that investors' inability to value distressed securities gives rise to the documented anomalies. 


\section{Appendix A: Numerical Details on Valuation Model}

In this appendix we summarize the numerical algorithm that we use to compute the value of equity of a distressed firm as well the optimal default boundary.

For convenience we introduce a new variable $y_{t}=\log \left(x_{t}\right)$, that follows an arithmetic Browninan motion under the risk-neutral measure:

$$
d y_{t}=\left(\mu_{Q}-\frac{\sigma^{2}}{2}\right) d t+\sigma d W_{t}
$$

We then discretize the problem by using a two-dimensional grid $N_{y} \times N_{t}$ with the corresponding increments of $y$ and $t$ given by $d y$ and $d t$, where $d y=\left(y_{\max }-y_{\min }\right) / N_{y}$ and $d t=T / N_{t}$, where $T$ is some terminal value. In our model the firm becomes debt-free after five years (when the long-term debt is repaid) but continues to pay the fixed cost (so the firm has a positive probability of abandoning operations even after debt is repaid) and is still subject to the distress cost $\eta$ (which kicks in whenever the net cash flow to equity holders falls below zero). At time $T$ we approximate the value of equity by the corresponding value of an unlevered firm with no financing constraints but still subject to the fixed cost payment $F$. It is straightforward to show that this value is given by:

$$
E\left(y_{T}\right)= \begin{cases}\frac{e^{y_{T}}}{r-\mu_{Q}}-\frac{F}{r}-\left(\frac{e^{y_{T}}}{x_{l}}\right)^{\beta}\left(\frac{x_{l}}{r-\mu_{Q}}-\frac{F}{r}\right) & \text { if } \quad y_{T}>\log \left(x_{l}\right) \\ 0 & \text { otherwise }\end{cases}
$$

where $x_{l}$ is the optimal exit boundary of an unconstrained firm given by $x_{l}=\frac{\beta}{\beta-1} \frac{F\left(r-\mu_{Q}\right)}{r}$, and $\beta=\frac{1}{2}-\frac{\mu_{Q}}{\sigma^{2}}-\sqrt{\left(\frac{1}{2}-\frac{\mu_{Q}}{\sigma^{2}}\right)^{2}+\frac{2 r}{\sigma^{2}}}$. The term $\frac{e^{y_{T}}}{r-\mu_{Q}}-\frac{F}{r}$ in (A2) is the present value of running an unlevered firm forever, while the term that follows is the value of the option to exit operation. (This value is still positive as long as $F>0$.)

We then iterate backwards using a binomial approximation of the Brownian motion (see, for example, Dixit and Pindyck (1994)). At each node the equityholders have an option to default. They will default if the present value (under $Q$ ) of running the firm for one more period is negative:

$$
\begin{aligned}
E(n d y, m d t)= & \max \left\{( 1 - r d t ) \left[p_{u} E((n+1) d y,(m+1) d t)+p_{d} E((n-1) d y,(m+1) d t]\right.\right. \\
& \left.+P R\left(e^{n d y}-C_{t}-F\right)\left(1-\tau+\eta 1_{e^{n d y}-C_{t}-F<0}\right) d t, 0\right\},
\end{aligned}
$$

where

$$
p_{u}=0.5+\left(\mu_{Q}-\frac{\sigma^{2}}{2}\right) \frac{\sqrt{d t}}{2 \sigma}, \quad p_{d}=1-p_{u}, \quad \text { and } \quad d y=\sigma \sqrt{d t},
$$

and $P R$ is the payout ratio.

Equation (A3) shows that at each node the value of equity is given by the discounted present value of equity the next time period plus the cash flows that equity holders receive over the time period $d t$. If this value is negative, then the firm is below the optimal default boundary so it is optimal for equity holders to default, in which case the value of equity is 
zero. (We assume that the absolute priority rule is enforced if bankruptcy occurs and the residual payout to equity holders is zero.)

To get a reasonable balance between execution speed and accuracy we set $d t=0.1$, $y_{\min }=-5, y_{\max }=10$, and $T=30$ in implementing this algorithm. 


\section{References}

Altman, Edward I., 1968, "Financial Ratios, Discriminant Analysis and the Prediction of Corporate Bankruptcy," Journal of Finance 23, 589-609.

Amihud, Yakov, 2002, "Illiquidity and Stock Returns: Cross-Section and Time-Series Effects," Journal of Financial Markets 5, 31-56.

Andrade, Gregor, and Steven Kaplan, 1998, "How Costly is Financial (not Economic) Distress? Evidence from Highly Leveraged Transactions that Become Distressed," Journal of Finance 53, 1443-1493.

Asness, Clifford S., Tobias J. Moskowitz, and Lasse H. Pedersen, 2009, "Value and Momentum Everywhere," Working paper.

Avramov, Doron, Tarun Chordia, Gregana Jostova, and Alexander Philipov, 2007, "Momentum and Credit Rating," Journal of Finance 62, 2503-2520.

Avramov, Doron, Tarun Chordia, Gregana Jostova, and Alexander Philipov, 2009, "Credit Ratings and the Cross-Section of Stock Returns," Journal of Financial Markets 12, 479-499.

Avramov, Doron, Tarun Chordia, Gregana Jostova, and Alexander Philipov, 2010, "Anomalies and Financial Distress," Working paper, http://ssrn.com/abstract=1593728.

Ball, Ray, and Ross Watts, 1972, "Some Time Series Properties of Accounting Income," Journal of Finance 27, 663-82.

Barberis, Nicholas, Andrei Shleifer, and Robert Vishny, 1998, "A Model of Investor Sentiment," Journal of Financial Economics 49, 307-343.

Benartzi, Shlomo, and Richard H. Thaler, 2001, "Naïve Diversification Strategies in Defined Contribution Saving Plans," American Economic Review 91, 79-98.

Brav, Alon, J.B. Heaton, and Si Li, 2010, "The Limits of Limits to Arbitrage," Review of Finance 14, 157-187.

Brealey, Richard, Stewart Myers, and Franklin Allen, 2011, Principles of Corporate Finance, McGraw-Hill/Irwin.

Campbell, John Y., Jens Hilscher, and Jan Szilagyi, 2008, "In Search of Distress Risk," Journal of Finance 63, 2899-2939.

Chava, Sudheer, and Amiyatosh Purnanandam, 2010, "Is Default Risk Negatively Related to Stock Returns?," Review of Financial Studies 23, 2523-2559.

Da, Zhi, and Pengjie Gao, 2010, "Clientele Change, Liquidity Shock, and the Return on Financially Distressed Stocks," Journal of Financial and Quantitative Analysis 45, 2748. 
Delianedis, Gordon, and Robert Geske, 2003, "Credit Risk and Risk Neutral Default Probabilities: Information about Rating Migrations and Defaults," Working paper, Anderson School UCLA.

Dichev, Ilia, 1998, "Is the Risk of Bankruptcy a Systematic Risk?" Journal of Finance 53, 1141-1148.

Dixit, Avinash K., and Robert S. Pindyck, 1994, Investment Under Uncertainty, Princeton University Press, Princeton.

Doukas, John A., Chansog (Francis) Kim, and Christos Pantzalis, 2010, "Arbitrage Risk and Stock Mispricing," Journal of Financial and Quantitative Analysis 45, 907-934.

Duffie, Darrell, Leandro Saita, and Ke Wang, 2007, "Multiperiod Corporate Default Probabilities with Stochastic Covariates," Journal of Financial Economics 83, 635-665.

Elkamhi, Redouane, Jan Ericsson, and Christopher A. Parsons, 2011, "The Cost of Financial Distress and the Timing of Default," Journal of Financial Economics 47, 427-465.

Fama, Eugene F., and Kenneth R. French, 1992, "The Cross-Section of Expected Stock Returns," Journal of Finance 47, 427-465.

Fama, Eugene F., and Kenneth R. French, 1993, "Common Risk Factors in the Returns on Stocks and Bonds," Journal of Financial Economics 33, 3-56.

Foster, George, 1977, "Quarterly Accounting Data: Time Series Properties and PredictiveAbility Results," The Accounting Review 52, 1-21.

Franzen, Laurel A., Kimberly J. Rodgers, and Timothy T. Simin, 2011, "Measuring Distress Risk: The Effect of R\&D Intensity," forthcoming in Journal of Finance.

Geske, Robet, 1978, "The Valuation of Compound Options," Journal of Financial Economics 7, 63-81.

Goldstein, Robert, Nengjiu Ju, and Hayne E. Leland, 2001, "An EBIT-Based Model of Dynamic Capital Structure," Journal of Business 74, 483-512.

Griffin, John M., and Michael L. Lemmon, 2002, "Book-to-Market Equity, Distress Risk, and Stock Returns," Journal of Finance 57, 2317-2336.

Hawawini, Gabriel, and Donald B. Keim, 1999, "The Cross Section of Common Stock Returns: A Review of the Evidence and Some New Findings," Working paper 8-99, Wharton School.

Hirshleifer, David, and Siew H. Teoh, 2003, "Limited Attention, Information Disclosure, and Financial Reporting," Journal of Accounting and Economics 36, 337-386.

Jegadeesh, Narasimhan, and Sheridan Titman, 1993, "Returns to Buying Winners and Selling Losers: Implications for Stock Market Efficiency," Journal of Finance 48, 65-91. 
Kapadia, Nishad, 2011, "Tracking Down Distress Risk," Journal of Financial Economics 102, 167-182.

Lakonishok, Josef, Andrei Shleifer, and Robert Vishny, 1994, "Contrarian Investment, Extrapolation, and Risk," Journal of Finance 49, 1541-1578.

Merton, Robert C., 1974, "On the Pricing of Corporate Debt: The Risk Structure of Interest Rates," Journal of Finance 29, 449-470.

Ohlson, James A., 1980, "Financial Ratios and the Probabilistic Prediction of Bankruptcy," Journal of Accounting Research 18, 109-131.

Park, James L., 2011, "Equity Issuance and Returns to Distressed Firms," Working paper, University of British Columbia, http://ssrn . com/abstract=1814251.

Poteshman, Allen, and Vitaly Serbin, 2003, "Clearly Irrational Market Behavior: Evidence from the Early Exercise of Exchange Traded Options," Journal of Finance 58, 37-70.

Shleifer, Andrei, and Robert W. Vishny, 1997, "The Limits to Arbitrage," Journal of Finance $52,35-55$.

Shumway, Tyler, 1997, "The Delisting Bias in CRSP Data," Journal of Finance 52, 327-340.

Shumway, Tyler, 2001, "Forecasting Bankruptcy More Accurately: A Simple Hazard Model," Journal of Business 74, 101-124.

Vassalou, Maria, and Yuhang Xing, 2004, "Default Risk in Equity Returns," Journal of Finance 59, 831-868.

Weiss, Lawrence A., 1990, "Bankruptcy Resolution: Direct Costs and Violation of Priority of Claims," Journal of Financial Economics 27, 285-314. 


\section{Table 1: Characteristics of Distress-Risk Sorted Portfolios}

Each calendar quarter, we sort all stocks into ten equal-sized deciles (least distressed, D1, to most distressed, D10) based on CHS (2008) distress-risk measure using current market data and quarterly accounting data of the previous quarter. The table presents descriptive statistics for each portfolio, where for all variables, observations outside the top and the bottom percentiles are excluded. Size is equity value (in millions of dollars). Market-to-book ratio is equity market value divided by equity book value. Market beta is measured by regression of stock return on market return over the past 36 months. Standard deviation (reported in percent) is calculated from market-adjusted stock return in the past year. Share turnover is trading volume scaled by total shares outstanding. Amihud's illiquidity is the monthly average of daily ratios of absolute return to dollar trading volume (in millions). Percent of firms with negative earnings is based on the net income in the previous calendar year. Number of analysts covering the firm is measured by the number of forecasts appearing in IBES. Standard deviation of analysts' forecasts is also calculated from IBES data. Equity issuance (reported in percent) is measured by the difference between the sale and purchase of common and preferred stock during the year, scaled by equity market value at the beginning of the year. Institutional ownership (reported in percent) is the sum of all shares held by institutions divided by total shares outstanding. The sample period is 1983 to 2009. 


\begin{tabular}{|c|c|c|c|c|c|c|c|c|c|c|c|}
\hline & & D1 & D2 & D3 & D4 & D5 & D6 & D7 & $\mathrm{D} 8$ & D9 & $\mathrm{D} 10$ \\
\hline Size & $\begin{array}{l}\text { Mean } \\
\text { Median }\end{array}$ & $\begin{array}{c}2,108.1 \\
427.9\end{array}$ & $\begin{array}{c}2,782.8 \\
635.4\end{array}$ & $\begin{array}{c}2,259.5 \\
525.8\end{array}$ & $\begin{array}{c}1,792.5 \\
380.8\end{array}$ & $\begin{array}{c}1,433.5 \\
263.4\end{array}$ & $\begin{array}{c}1,168.1 \\
185.2\end{array}$ & $\begin{array}{l}646.3 \\
105.2\end{array}$ & $\begin{array}{c}300.0 \\
62.0\end{array}$ & $\begin{array}{c}167.7 \\
40.3\end{array}$ & $\begin{array}{l}57.4 \\
17.7\end{array}$ \\
\hline Market-to-book & $\begin{array}{l}\text { Mean } \\
\text { Median }\end{array}$ & $\begin{array}{l}2.10 \\
1.92\end{array}$ & $\begin{array}{l}2.30 \\
2.05\end{array}$ & $\begin{array}{l}2.15 \\
1.85\end{array}$ & $\begin{array}{l}1.97 \\
1.66\end{array}$ & $\begin{array}{l}1.82 \\
1.52\end{array}$ & $\begin{array}{l}1.74 \\
1.41\end{array}$ & $\begin{array}{l}1.71 \\
1.31\end{array}$ & $\begin{array}{l}1.78 \\
1.25\end{array}$ & $\begin{array}{l}1.90 \\
1.24\end{array}$ & $\begin{array}{l}1.95 \\
1.23\end{array}$ \\
\hline Market beta & $\begin{array}{l}\text { Mean } \\
\text { Median }\end{array}$ & $\begin{array}{l}0.98 \\
0.91\end{array}$ & $\begin{array}{l}1.02 \\
0.96\end{array}$ & $\begin{array}{l}1.03 \\
0.95\end{array}$ & $\begin{array}{l}1.03 \\
0.95\end{array}$ & $\begin{array}{l}1.03 \\
0.93\end{array}$ & $\begin{array}{l}1.02 \\
0.90\end{array}$ & $\begin{array}{l}1.02 \\
0.90\end{array}$ & $\begin{array}{l}1.09 \\
0.97\end{array}$ & $\begin{array}{l}1.22 \\
1.14\end{array}$ & $\begin{array}{l}1.37 \\
1.31\end{array}$ \\
\hline Stdev of stock returns & $\begin{array}{l}\text { Mean } \\
\text { Median }\end{array}$ & $\begin{array}{l}2.4 \\
2.2\end{array}$ & $\begin{array}{l}2.4 \\
2.2\end{array}$ & $\begin{array}{l}2.5 \\
2.3\end{array}$ & $\begin{array}{l}2.7 \\
2.5\end{array}$ & $\begin{array}{l}2.8 \\
2.6\end{array}$ & $\begin{array}{l}3.0 \\
2.7\end{array}$ & $\begin{array}{l}3.5 \\
3.2\end{array}$ & $\begin{array}{l}4.3 \\
4.0\end{array}$ & $\begin{array}{l}5.4 \\
5.1\end{array}$ & $\begin{array}{l}7.4 \\
7.0\end{array}$ \\
\hline Share turnover & $\begin{array}{l}\text { Mean } \\
\text { Median }\end{array}$ & $\begin{array}{l}0.11 \\
0.07\end{array}$ & $\begin{array}{l}0.11 \\
0.08\end{array}$ & $\begin{array}{l}0.11 \\
0.08\end{array}$ & $\begin{array}{l}0.11 \\
0.07\end{array}$ & $\begin{array}{l}0.10 \\
0.06\end{array}$ & $\begin{array}{l}0.09 \\
0.05\end{array}$ & $\begin{array}{l}0.08 \\
0.05\end{array}$ & $\begin{array}{l}0.08 \\
0.04\end{array}$ & $\begin{array}{l}0.09 \\
0.05\end{array}$ & $\begin{array}{l}0.10 \\
0.05\end{array}$ \\
\hline Amihud's illiquidity & $\begin{array}{l}\text { Mean } \\
\text { Median }\end{array}$ & $\begin{array}{l}0.90 \\
0.04\end{array}$ & $\begin{array}{l}0.77 \\
0.02\end{array}$ & $\begin{array}{l}0.90 \\
0.03\end{array}$ & $\begin{array}{l}1.25 \\
0.05\end{array}$ & $\begin{array}{l}1.72 \\
0.09\end{array}$ & $\begin{array}{l}2.51 \\
0.15\end{array}$ & $\begin{array}{l}4.15 \\
0.38\end{array}$ & $\begin{array}{l}7.21 \\
0.88\end{array}$ & $\begin{array}{c}12.43 \\
1.93\end{array}$ & $\begin{array}{c}23.10 \\
5.57\end{array}$ \\
\hline$\%$ of negative earnings & Mean & 2.4 & 4.0 & 6.8 & 10.3 & 15.0 & 20.5 & 30.1 & 46.1 & 68.9 & 89.6 \\
\hline Number of analysts & $\begin{array}{l}\text { Mean } \\
\text { Median }\end{array}$ & $\begin{array}{l}4.42 \\
3.19\end{array}$ & $\begin{array}{l}5.05 \\
3.88\end{array}$ & $\begin{array}{l}4.73 \\
3.59\end{array}$ & $\begin{array}{l}4.21 \\
3.19\end{array}$ & $\begin{array}{l}3.86 \\
2.92\end{array}$ & $\begin{array}{l}3.49 \\
2.59\end{array}$ & $\begin{array}{l}3.04 \\
2.17\end{array}$ & $\begin{array}{l}2.80 \\
2.03\end{array}$ & $\begin{array}{l}2.49 \\
1.74\end{array}$ & $\begin{array}{l}2.02 \\
1.48\end{array}$ \\
\hline Stdev of analysts' forecasts & $\begin{array}{l}\text { Mean } \\
\text { Median }\end{array}$ & $\begin{array}{l}0.04 \\
0.02\end{array}$ & $\begin{array}{l}0.03 \\
0.02\end{array}$ & $\begin{array}{l}0.04 \\
0.02\end{array}$ & $\begin{array}{l}0.04 \\
0.03\end{array}$ & $\begin{array}{l}0.05 \\
0.03\end{array}$ & $\begin{array}{l}0.06 \\
0.04\end{array}$ & $\begin{array}{l}0.07 \\
0.05\end{array}$ & $\begin{array}{l}0.09 \\
0.06\end{array}$ & $\begin{array}{l}0.11 \\
0.08\end{array}$ & $\begin{array}{l}0.14 \\
0.12\end{array}$ \\
\hline Equity issuance & $\begin{array}{l}\text { Mean } \\
\text { Median }\end{array}$ & $\begin{array}{l}-0.4 \\
-0.1\end{array}$ & $\begin{array}{l}0.0 \\
0.0\end{array}$ & $\begin{array}{l}0.4 \\
0.1\end{array}$ & $\begin{array}{l}0.8 \\
0.1\end{array}$ & $\begin{array}{l}1.2 \\
0.1\end{array}$ & $\begin{array}{l}1.5 \\
0.1\end{array}$ & $\begin{array}{l}2.1 \\
0.1\end{array}$ & $\begin{array}{l}2.9 \\
0.1\end{array}$ & $\begin{array}{l}4.4 \\
0.2\end{array}$ & $\begin{array}{l}9.9 \\
1.0\end{array}$ \\
\hline Institutional ownership & $\begin{array}{l}\text { Mean } \\
\text { Median }\end{array}$ & $\begin{array}{l}46.7 \\
48.4\end{array}$ & $\begin{array}{l}49.3 \\
51.9\end{array}$ & $\begin{array}{l}47.1 \\
49.1\end{array}$ & $\begin{array}{l}43.7 \\
44.3\end{array}$ & $\begin{array}{l}39.6 \\
38.4\end{array}$ & $\begin{array}{l}34.9 \\
31.6\end{array}$ & $\begin{array}{l}30.0 \\
25.1\end{array}$ & $\begin{array}{l}25.5 \\
19.3\end{array}$ & $\begin{array}{l}22.2 \\
16.3\end{array}$ & $\begin{array}{l}15.6 \\
10.0\end{array}$ \\
\hline
\end{tabular}




\section{Table 2: Returns to Distress-Risk Sorted Portfolios}

Each calendar quarter, we sort all stocks into ten equal-sized deciles (least distressed, D1, to most distressed, D10) based on CHS (2008) distress-risk measure using current market data and quarterly accounting data of the previous quarter. We calculate value-weighted monthly return of each portfolio in the subsequent quarter. The table shows the portfolios' mean excess monthly returns (in excess of the riskfree rate) and alphas from factor models. The CAPM one-factor model uses the market factor. The three factors in the 3-factor model are the Fama and French (1993) factors. The four factors in the 4-factor model are the Fama-French factors augmented with a momentum factor. All returns and alphas are in percent per month and the corresponding $t$-statistics are in parentheses. The sample period is 1983 to 2009 .

\begin{tabular}{lccccccccccc}
\hline Decile & $\mathrm{D} 1$ & $\mathrm{D} 2$ & $\mathrm{D} 3$ & $\mathrm{D} 4$ & $\mathrm{D} 5$ & $\mathrm{D} 6$ & $\mathrm{D} 7$ & $\mathrm{D} 8$ & $\mathrm{D} 9$ & $\mathrm{D} 10$ & D1-D10 \\
\hline \multirow{3}{*}{ Excess return } & 0.82 & 0.69 & 0.47 & 0.66 & 0.51 & 0.46 & 0.43 & -0.07 & -0.04 & -0.62 & 1.44 \\
& $(3.42)$ & $(2.96)$ & $(1.87)$ & $(2.56)$ & $(1.81)$ & $(1.39)$ & $(1.15)$ & $(-0.15)$ & $(-0.08)$ & $(-1.00)$ & $(2.69)$ \\
CAPM alpha & 0.33 & 0.19 & -0.08 & 0.11 & -0.09 & -0.22 & -0.30 & -0.94 & -0.94 & -1.57 & 1.90 \\
& $(3.10)$ & $(2.57)$ & $(-1.13)$ & $(1.28)$ & $(-0.99)$ & $(-1.47)$ & $(-1.54)$ & $(-3.72)$ & $(-2.84)$ & $(-3.37)$ & $(3.80)$ \\
3-factor alpha & 0.39 & 0.21 & -0.05 & 0.08 & -0.19 & -0.38 & -0.45 & -1.14 & -0.99 & -1.59 & 1.99 \\
& $(3.68)$ & $(2.85)$ & $(-0.69)$ & $(1.05)$ & $(-2.12)$ & $(-2.70)$ & $(-2.39)$ & $(-5.09)$ & $(-3.45)$ & $(-4.04)$ & $(4.58)$ \\
4-factor alpha & 0.24 & 0.09 & -0.05 & 0.16 & -0.07 & -0.10 & -0.03 & -0.60 & -0.43 & -0.88 & 1.12 \\
& $(2.41)$ & $(1.41)$ & $(-0.67)$ & $(1.95)$ & $(-0.85)$ & $(-0.84)$ & $(-0.17)$ & $(-3.47)$ & $(-1.75)$ & $(-2.50)$ & $(3.01)$ \\
\hline
\end{tabular}




\section{Table 3: Returns to Double-Sorted Portfolios}

We sort all stocks independently into five quintiles (least distressed, D1, to most distressed, D5) and another stock characteristic. The distress-risk measure is based on CHS (2008) using current market data and quarterly accounting data of the previous quarter. The stock characteristic is market capitalization $(\mathrm{S} 1=$ small, $\mathrm{S} 5=\mathrm{big}$ ) in Panel $\mathrm{A}$, market-to-book ratio (MB1=value, MB5=growth) in Panel $\mathrm{B}$, and past six-month returns (MO1=losers, MO5=winners) in Panel C. Market-to-book ratio is calculated as the ratio of current market value divided by book value of previous quarter and we skip one month in calculating the six-month returns. Sorting is done at the end of each calendar quarter and the holding period is three months for Panels A and B. Sorting is done at the end of each month and the holding period is six months in Panel $\mathrm{C}$ (the resulting overlapping portfolios are equally-weighted). The table shows the value-weighted mean excess monthly returns (in excess of the riskfree rate) and CAPM alphas. All returns and alphas are in percent per month and the corresponding $t$-statistics are in parentheses. The sample period is 1983 to 2009.

\begin{tabular}{|c|c|c|c|c|c|c|c|c|c|c|c|c|}
\hline & $\overline{\mathrm{D} 1}$ & D2 & D3 & $\overline{\mathrm{D} 4}$ & D5 & $\mathrm{D} 1-\mathrm{D} 5$ & D1 & D2 & D3 & $\mathrm{D} 4$ & D5 & $\overline{\mathrm{D} 1-\mathrm{D} 5}$ \\
\hline & \multicolumn{6}{|c|}{ Excess return } & \multicolumn{6}{|c|}{ CAPM alpha } \\
\hline \multicolumn{13}{|c|}{ Panel A: Distress-risk and size sorted portfolios } \\
\hline S1 (small) & $\begin{array}{c}1.48 \\
(5.45)\end{array}$ & $\begin{array}{c}1.27 \\
(4.27)\end{array}$ & $\begin{array}{c}0.84 \\
(2.95)\end{array}$ & $\begin{array}{c}0.85 \\
(2.75)\end{array}$ & $\begin{array}{c}0.24 \\
(0.45)\end{array}$ & $\begin{array}{c}1.24 \\
(3.32)\end{array}$ & $\begin{array}{c}1.08 \\
(5.31)\end{array}$ & $\begin{array}{c}0.85 \\
(3.69)\end{array}$ & $\begin{array}{c}0.42 \\
(1.97)\end{array}$ & $\begin{array}{c}0.40 \\
(1.72)\end{array}$ & $\begin{array}{c}-0.42 \\
(-0.95)\end{array}$ & $\begin{array}{c}1.50 \\
(4.19)\end{array}$ \\
\hline $\mathrm{S} 2$ & $\begin{array}{c}1.23 \\
(4.84)\end{array}$ & $\begin{array}{c}1.16 \\
(3.91)\end{array}$ & $\begin{array}{c}0.71 \\
(2.49)\end{array}$ & $\begin{array}{c}0.42 \\
(1.26)\end{array}$ & $\begin{array}{c}-0.34 \\
(-0.63)\end{array}$ & $\begin{array}{c}1.58 \\
(4.23)\end{array}$ & $\begin{array}{c}0.81 \\
(4.81)\end{array}$ & $\begin{array}{c}0.66 \\
(3.42)\end{array}$ & $\begin{array}{c}0.24 \\
(1.26)\end{array}$ & $\begin{array}{c}-0.14 \\
(-0.62)\end{array}$ & $\begin{array}{c}-1.13 \\
(-2.77)\end{array}$ & $\begin{array}{c}1.94 \\
(5.74)\end{array}$ \\
\hline S3 & $\begin{array}{c}1.03 \\
(3.68)\end{array}$ & $\begin{array}{c}0.85 \\
(2.78)\end{array}$ & $\begin{array}{c}0.75 \\
(2.43)\end{array}$ & $\begin{array}{c}0.38 \\
(0.97)\end{array}$ & $\begin{array}{c}-0.22 \\
(-0.39)\end{array}$ & $\begin{array}{c}1.25 \\
(3.12)\end{array}$ & $\begin{array}{c}0.52 \\
(3.26)\end{array}$ & $\begin{array}{c}0.29 \\
(1.69)\end{array}$ & $\begin{array}{c}0.18 \\
(1.06)\end{array}$ & $\begin{array}{l}-0.31 \\
(-1.31)\end{array}$ & $\begin{array}{l}-1.11 \\
(-2.76)\end{array}$ & $\begin{array}{c}1.64 \\
(4.48)\end{array}$ \\
\hline $\mathrm{S} 4$ & $\begin{array}{c}0.90 \\
(3.16)\end{array}$ & $\begin{array}{c}0.76 \\
(2.53)\end{array}$ & $\begin{array}{c}0.74 \\
(2.43)\end{array}$ & $\begin{array}{c}0.42 \\
(1.03)\end{array}$ & $\begin{array}{c}0.00 \\
(0.00)\end{array}$ & $\begin{array}{c}0.90 \\
(2.13)\end{array}$ & $\begin{array}{c}0.35 \\
(2.51)\end{array}$ & $\begin{array}{c}0.17 \\
(1.24)\end{array}$ & $\begin{array}{c}0.14 \\
(1.03)\end{array}$ & $\begin{array}{c}-0.33 \\
(-1.49)\end{array}$ & $\begin{array}{c}-0.97 \\
(-2.52)\end{array}$ & $\begin{array}{c}1.32 \\
(3.46)\end{array}$ \\
\hline S5 (big) & $\begin{array}{c}0.70 \\
(3.03)\end{array}$ & $\begin{array}{c}0.59 \\
(2.41)\end{array}$ & $\begin{array}{c}0.47 \\
(1.56)\end{array}$ & $\begin{array}{c}0.28 \\
(0.68)\end{array}$ & $\begin{array}{l}-0.06 \\
(-0.09)\end{array}$ & $\begin{array}{c}0.76 \\
(1.48)\end{array}$ & $\begin{array}{c}0.22 \\
(2.98)\end{array}$ & $\begin{array}{c}0.06 \\
(1.14)\end{array}$ & $\begin{array}{l}-0.15 \\
(-1.40)\end{array}$ & $\begin{array}{l}-0.49 \\
(-2.19)\end{array}$ & $\begin{array}{c}-0.97 \\
(-2.20)\end{array}$ & $\begin{array}{c}1.19 \\
(2.50)\end{array}$ \\
\hline $\mathrm{S} 1-\mathrm{S} 5$ & $\begin{array}{c}0.78 \\
(3.38)\end{array}$ & $\begin{array}{c}0.69 \\
(2.68)\end{array}$ & $\begin{array}{c}0.37 \\
(1.40)\end{array}$ & $\begin{array}{c}0.56 \\
(1.78)\end{array}$ & $\begin{array}{c}0.30 \\
(0.64)\end{array}$ & & $\begin{array}{c}0.86 \\
(3.76)\end{array}$ & $\begin{array}{c}0.79 \\
(3.12)\end{array}$ & $\begin{array}{c}0.58 \\
(2.34)\end{array}$ & $\begin{array}{c}0.90 \\
(3.21)\end{array}$ & $\begin{array}{c}0.55 \\
(1.23)\end{array}$ & \\
\hline
\end{tabular}




\begin{tabular}{|c|c|c|c|c|c|c|c|c|c|c|c|c|}
\hline & D1 & D2 & D3 & $\mathrm{D} 4$ & D5 & $\mathrm{D} 1-\mathrm{D} 5$ & D1 & D2 & D3 & $\mathrm{D} 4$ & D5 & D1-D5 \\
\hline & \multicolumn{6}{|c|}{ Excess return } & \multicolumn{6}{|c|}{ CAPM alpha } \\
\hline \multicolumn{13}{|c|}{ Panel B: Distress-risk and market-to-book sorted portfolios } \\
\hline MB2 & $\begin{array}{c}0.89 \\
(3.65)\end{array}$ & $\begin{array}{c}0.75 \\
(3.10)\end{array}$ & $\begin{array}{c}0.91 \\
(2.96)\end{array}$ & $\begin{array}{c}0.48 \\
(1.21)\end{array}$ & $\begin{array}{c}0.04 \\
(0.07)\end{array}$ & $\begin{array}{c}0.85 \\
(1.83)\end{array}$ & $\begin{array}{c}0.45 \\
(3.18)\end{array}$ & $\begin{array}{c}0.33 \\
(2.21)\end{array}$ & $\begin{array}{c}0.35 \\
(2.00)\end{array}$ & $\begin{array}{c}-0.19 \\
(-0.74)\end{array}$ & $\begin{array}{c}-0.83 \\
(-2.08)\end{array}$ & $\begin{array}{c}1.28 \\
(3.02)\end{array}$ \\
\hline MB4 & $\begin{array}{c}0.67 \\
(2.79)\end{array}$ & $\begin{array}{c}0.59 \\
(2.31)\end{array}$ & $\begin{array}{c}0.59 \\
(1.90)\end{array}$ & $\begin{array}{c}0.26 \\
(0.64)\end{array}$ & $\begin{array}{c}-0.47 \\
(-0.80)\end{array}$ & $\begin{array}{c}1.15 \\
(2.21)\end{array}$ & $\begin{array}{c}0.19 \\
(1.86)\end{array}$ & $\begin{array}{c}0.07 \\
(0.72)\end{array}$ & $\begin{array}{l}-0.01 \\
(-0.09)\end{array}$ & $\begin{array}{c}-0.42 \\
(-1.63)\end{array}$ & $\begin{array}{c}-1.36 \\
(-3.06)\end{array}$ & $\begin{array}{c}1.55 \\
(3.16)\end{array}$ \\
\hline MB5 (growth) & $\begin{array}{c}0.72 \\
(2.85)\end{array}$ & $\begin{array}{c}0.42 \\
(1.38)\end{array}$ & $\begin{array}{c}0.15 \\
(0.42)\end{array}$ & $\begin{array}{c}0.08 \\
(0.16)\end{array}$ & $\begin{array}{c}-0.93 \\
(-1.63)\end{array}$ & $\begin{array}{c}1.65 \\
(3.50)\end{array}$ & $\begin{array}{c}0.21 \\
(2.04)\end{array}$ & $\begin{array}{c}-0.20 \\
(-1.88)\end{array}$ & $\begin{array}{c}-0.56 \\
(-3.40)\end{array}$ & $\begin{array}{c}-0.83 \\
(-2.82)\end{array}$ & $\begin{array}{c}-1.81 \\
(-4.43)\end{array}$ & $\begin{array}{c}2.03 \\
(4.58)\end{array}$ \\
\hline MB1-MB5 & $\begin{array}{c}0.12 \\
(0.57)\end{array}$ & $\begin{array}{c}0.34 \\
(1.36)\end{array}$ & $\begin{array}{c}0.67 \\
(2.50)\end{array}$ & $\begin{array}{c}0.30 \\
(0.73)\end{array}$ & $\begin{array}{c}0.78 \\
(1.98)\end{array}$ & & $\begin{array}{c}0.24 \\
(1.22)\end{array}$ & $\begin{array}{c}0.52 \\
(2.22)\end{array}$ & $\begin{array}{c}0.85 \\
(3.26)\end{array}$ & $\begin{array}{c}0.46 \\
(1.13)\end{array}$ & $\begin{array}{c}0.77 \\
(1.94)\end{array}$ & \\
\hline MO2 & $\begin{array}{c}0.84 \\
(3.25)\end{array}$ & $\begin{array}{c}0.64 \\
(2.37)\end{array}$ & $\begin{array}{c}0.44 \\
(1.41)\end{array}$ & $\begin{array}{c}0.16 \\
(0.41)\end{array}$ & $\begin{array}{c}-0.14 \\
(-0.29)\end{array}$ & $\begin{array}{c}0.98 \\
(2.75)\end{array}$ & $\begin{array}{c}0.33 \\
(2.82)\end{array}$ & $\begin{array}{c}0.10 \\
(0.88)\end{array}$ & $\begin{array}{l}-0.18 \\
(-1.31)\end{array}$ & $\begin{array}{c}-0.58 \\
(-3.03)\end{array}$ & $\begin{array}{c}-0.97 \\
(-3.20)\end{array}$ & $\begin{array}{c}1.30 \\
(4.00)\end{array}$ \\
\hline MO3 & $\begin{array}{c}0.74 \\
(3.26)\end{array}$ & $\begin{array}{c}0.55 \\
(2.30)\end{array}$ & $\begin{array}{c}0.51 \\
(1.76)\end{array}$ & $\begin{array}{c}0.37 \\
(1.04)\end{array}$ & $\begin{array}{c}0.17 \\
(0.36)\end{array}$ & $\begin{array}{c}0.57 \\
(1.54)\end{array}$ & $\begin{array}{c}0.27 \\
(3.44)\end{array}$ & $\begin{array}{c}0.04 \\
(0.65)\end{array}$ & $\begin{array}{l}-0.07 \\
(-0.53)\end{array}$ & $\begin{array}{c}-0.32 \\
(-1.87)\end{array}$ & $\begin{array}{c}-0.61 \\
(-2.00)\end{array}$ & $\begin{array}{c}0.88 \\
(2.54)\end{array}$ \\
\hline MO4 & $\begin{array}{c}0.70 \\
(3.04)\end{array}$ & $\begin{array}{c}0.57 \\
(2.36)\end{array}$ & $\begin{array}{c}0.54 \\
(1.97)\end{array}$ & $\begin{array}{c}0.40 \\
(1.24)\end{array}$ & $\begin{array}{c}0.32 \\
(0.70)\end{array}$ & $\begin{array}{c}0.38 \\
(1.07)\end{array}$ & $\begin{array}{c}0.23 \\
(2.74)\end{array}$ & $\begin{array}{c}0.06 \\
(0.87)\end{array}$ & $\begin{array}{c}-0.02 \\
(-0.23)\end{array}$ & $\begin{array}{c}-0.22 \\
(-1.27)\end{array}$ & $\begin{array}{c}-0.46 \\
(-1.58)\end{array}$ & $\begin{array}{c}0.69 \\
(2.06)\end{array}$ \\
\hline MO5 (winners) & $\begin{array}{c}0.80 \\
(2.68)\end{array}$ & $\begin{array}{c}0.70 \\
(2.25)\end{array}$ & $\begin{array}{c}0.67 \\
(1.96)\end{array}$ & $\begin{array}{c}0.54 \\
(1.34)\end{array}$ & $\begin{array}{c}0.58 \\
(1.20)\end{array}$ & $\begin{array}{c}0.22 \\
(0.66)\end{array}$ & $\begin{array}{c}0.23 \\
(1.54)\end{array}$ & $\begin{array}{c}0.09 \\
(0.62)\end{array}$ & $\begin{array}{c}0.00 \\
(0.00)\end{array}$ & $\begin{array}{c}-0.21 \\
(-0.95)\end{array}$ & $\begin{array}{c}-0.24 \\
(-0.75)\end{array}$ & $\begin{array}{c}0.46 \\
(1.45)\end{array}$ \\
\hline MO5-MO1 & $\begin{array}{c}-0.19 \\
(-0.71)\end{array}$ & $\begin{array}{c}0.16 \\
(0.60)\end{array}$ & $\begin{array}{c}0.21 \\
(0.76)\end{array}$ & $\begin{array}{c}0.71 \\
(2.21)\end{array}$ & $\begin{array}{c}1.19 \\
(3.60)\end{array}$ & & $\begin{array}{c}-0.13 \\
(-0.50)\end{array}$ & $\begin{array}{c}0.21 \\
(0.78)\end{array}$ & $\begin{array}{c}0.24 \\
(0.85)\end{array}$ & $\begin{array}{c}0.80 \\
(2.48)\end{array}$ & $\begin{array}{c}1.31 \\
(3.98)\end{array}$ & \\
\hline
\end{tabular}




\section{Table 4: Inputs to Valuation Model}

Each calendar quarter, we sort all stocks into five quintiles (least distressed, D1, to most distressed, D5) based on CHS (2008) distress-risk measure using current market data and quarterly accounting data of the previous quarter. We calculated equity values of stocks in the most distressed quintile using the valuation model of Section 3. This table reports the input parameters used in this valuation model. There are three categories of parameters. The parameters in the first category are kept constant for all firms and all months. Those in the second category are 3-digit SIC industry averages over the last three years. Finally, parameters in the third category are firm-month specific. Further details on the valuation model are provided in the text. The sample period is 1983 to 2009.

\begin{tabular}{|c|c|c|c|c|}
\hline Input variable & Value used in the model & Mean & Median & StDev \\
\hline $\begin{array}{l}\text { Coupon rate } \\
\text { Distress cost, } \eta \\
\text { Corporate tax rate, } \tau\end{array}$ & $\begin{array}{c}8.0 \% \\
10.0 \% \\
35.0 \%\end{array}$ & & & \\
\hline $\begin{array}{l}\text { Risk-free rate, } r \\
R_{A} \\
\text { Payout ratio, } P R \\
\text { Capex to sales ratio, } C S R \\
\text { Volatility, } \sigma \text { (annualized) }\end{array}$ & $\begin{array}{c}\text { Short term rate from Ken French's website } \\
\text { Average industry cost of assets in the last three years } \\
\text { Zero for the first five years then } 15 \% \\
\text { Average industry CSR in the last three years } \\
\text { Quarterly volatility of Sales }\end{array}$ & $\begin{array}{l}4.64 \% \\
8.84 \%\end{array}$ & $\begin{array}{l}4.80 \% \\
8.77 \%\end{array}$ & $\begin{array}{l}2.41 \% \\
2.60 \%\end{array}$ \\
\hline $\begin{array}{l}\text { Short term debt } \\
\text { Long term debt }\end{array}$ & $\begin{array}{l}\text { Annual compustat item } D L C C \\
\text { Annual compustat item } D L T\end{array}$ & $\begin{array}{l}\text { As a p } \\
0.122 \\
0.245\end{array}$ & $\begin{array}{c}\text { rcentage } \\
0.040 \\
0.128\end{array}$ & $\begin{array}{l}\text { otal value } \\
0.180 \\
0.273 \\
\text { of sales }\end{array}$ \\
\hline $\begin{array}{l}\text { Fixed Cost } \\
\text { Gross Margin }\end{array}$ & $\begin{array}{c}\text { Annual compustat item } X G N A \\
\text { Sales - COGS from annual Compustat }\end{array}$ & $\begin{array}{c}0.489 \\
-0.047\end{array}$ & $\begin{array}{l}0.271 \\
0.271\end{array}$ & $\begin{array}{l}0.622 \\
1.096\end{array}$ \\
\hline
\end{tabular}




\section{Table 5: Characteristics of Portfolios sorted on Distress Risk and Relative Model Value}

Each calendar quarter, we sort all stocks into five quintiles (least distressed, D1, to most distressed, D5) based on CHS (2008) distress-risk measure using current market data and quarterly accounting data of the previous quarter. All stock in the D5 quintile (most distressed firms) are further sorted into five equal-sized portfolios according to the ratio of the equity value implied by our valuation model of and the actual equity value $(\mathrm{R} 1=$ most overvalued, $\mathrm{R} 5=$ most undervalued). Column with heading 'No value' reports statistics on stocks for which we are unable to compute model value. We calculate value-weighted monthly return of each portfolio in the subsequent quarter. The table shows the portfolios' mean excess monthly returns (in excess of the riskfree rate) and alphas from factor models. The CAPM one-factor model uses the market factor. The three factors in the 3-factor model are the Fama and French (1993) factors. The four factors in the 4-factor model are the Fama-French factors augmented with a momentum factor. All returns and alphas are in percent per month and the corresponding $t$-statistics are in parentheses. Number of observations is the number of firm-months in the respective quintiles. We also report size (in millions of dollars), market-to-book ratio (equity market value divided by equity book value), past six-month returns, and equity issuance of stocks in these quintiles. Equity issuance (reported in percent) is measured by the difference between the sale and purchase of common and preferred stock during the year, scaled by equity market value at the beginning of the year. The sample period is 1983 to 2009 .

\begin{tabular}{|c|c|c|c|c|c|c|c|c|}
\hline & & No value & $\mathrm{R} 1$ & $\mathrm{R} 2$ & R3 & $\mathrm{R} 4$ & R5 & $\mathrm{R} 5-\mathrm{R} 1$ \\
\hline Number observations & & 63,160 & 45,731 & 45,916 & 45,921 & 45,915 & 45,805 & \\
\hline Size & $\begin{array}{l}\text { Mean } \\
\text { Median }\end{array}$ & $\begin{array}{c}157.2 \\
26.8\end{array}$ & $\begin{array}{c}150.1 \\
27.7\end{array}$ & $\begin{array}{c}126.3 \\
22.3\end{array}$ & $\begin{array}{c}119.7 \\
18.2\end{array}$ & $\begin{array}{l}74.0 \\
14.1\end{array}$ & $\begin{array}{l}43.9 \\
10.4\end{array}$ & \\
\hline Market-to-book & $\begin{array}{l}\text { Mean } \\
\text { Median }\end{array}$ & $\begin{array}{c}18.24 \\
1.35\end{array}$ & $\begin{array}{c}42.51 \\
1.63\end{array}$ & $\begin{array}{l}4.98 \\
1.85\end{array}$ & $\begin{array}{l}2.98 \\
1.34\end{array}$ & $\begin{array}{l}1.44 \\
0.95\end{array}$ & $\begin{array}{l}1.24 \\
0.57\end{array}$ & \\
\hline Past return & $\begin{array}{l}\text { Mean } \\
\text { Median }\end{array}$ & $\begin{array}{c}9.32 \\
-16.09\end{array}$ & $\begin{array}{c}10.86 \\
-17.65\end{array}$ & $\begin{array}{c}13.38 \\
-16.67\end{array}$ & $\begin{array}{c}8.83 \\
-15.97\end{array}$ & $\begin{array}{c}1.39 \\
-16.92\end{array}$ & $\begin{array}{l}-4.26 \\
-21.64\end{array}$ & \\
\hline Equity issuance & $\begin{array}{l}\text { Mean } \\
\text { Median }\end{array}$ & & $\begin{array}{c}11.49 \\
0.77\end{array}$ & $\begin{array}{c}10.07 \\
0.74\end{array}$ & $\begin{array}{l}7.79 \\
0.30\end{array}$ & $\begin{array}{l}6.32 \\
0.12\end{array}$ & $\begin{array}{l}5.59 \\
0.00\end{array}$ & \\
\hline Excess return & & $\begin{array}{c}-0.42 \\
(-0.71)\end{array}$ & $\begin{array}{l}-1.16 \\
(-1.85)\end{array}$ & $\begin{array}{c}-0.52 \\
(-0.88)\end{array}$ & $\begin{array}{l}-0.09 \\
(-0.16)\end{array}$ & $\begin{array}{c}1.04 \\
(1.80)\end{array}$ & $\begin{array}{c}-0.03 \\
(-0.05)\end{array}$ & $\begin{array}{c}1.13 \\
(2.32)\end{array}$ \\
\hline CAPM alpha & & $\begin{array}{l}-1.26 \\
(-2.83)\end{array}$ & $\begin{array}{l}-2.08 \\
(-4.80)\end{array}$ & $\begin{array}{l}-1.36 \\
(-3.19)\end{array}$ & $\begin{array}{l}-0.94 \\
(-2.19)\end{array}$ & $\begin{array}{c}0.29 \\
(0.63)\end{array}$ & $\begin{array}{c}-0.84 \\
(-1.72)\end{array}$ & $\begin{array}{l}1.25 \\
(2.57)\end{array}$ \\
\hline 3 -factor alpha & & $\begin{array}{l}-1.29 \\
(-3.20)\end{array}$ & $\begin{array}{l}-1.99 \\
(-5.21)\end{array}$ & $\begin{array}{l}-1.23 \\
(-3.61)\end{array}$ & $\begin{array}{l}-0.97 \\
(-2.60)\end{array}$ & $\begin{array}{c}0.10 \\
(0.26)\end{array}$ & $\begin{array}{l}-1.30 \\
(-3.07)\end{array}$ & $\begin{array}{c}0.70 \\
(1.56)\end{array}$ \\
\hline 4-factor alpha & & $\begin{array}{l}-0.84 \\
(-2.16)\end{array}$ & $\begin{array}{l}-1.51 \\
(-4.18)\end{array}$ & $\begin{array}{l}-0.68 \\
(-2.24)\end{array}$ & $\begin{array}{c}-0.34 \\
(-1.02)\end{array}$ & $\begin{array}{c}0.76 \\
(2.11)\end{array}$ & $\begin{array}{l}-0.50 \\
(-1.40)\end{array}$ & $\begin{array}{c}1.02 \\
(2.28)\end{array}$ \\
\hline
\end{tabular}




\section{Table 6: Returns to Value Gap Sorted Portfolios}

We sort all stocks into five quintiles (least distressed, D1, to most distressed, D5) based on CHS (2008) distress-risk measure using current market data and quarterly accounting data of the previous quarter. All stock in the D5 quintile (most distressed firms) are further sorted independently into three portfolios based on value gap and three portfolios based on a stock characteristic. Value gap is defined as the absolute value of the log of the ratio of the equity value implied by our valuation model and the actual equity value. Portfolio VG1 has the least value gap (most fairly valued stocks) while portfolio VG3 has the highest value gap (most misvalued stocks). The stock characteristic is market capitalization ( $\mathrm{S} 1=$ small, $\mathrm{S} 3=\mathrm{big}$ ) in Panel $\mathrm{A}$, market-to-book ratio (MB1=value, MB3=growth) in Panel B, and past six-month returns (MO1=losers, MO3=winners) in Panel C. Market-to-book ratio is calculated as the ratio of current market value divided by book value of previous quarter and we skip one month in calculating the six-month returns. Sorting is done at the end of each calendar quarter and the holding period is three months for Panels A and B. Sorting is done at the end of each month and the holding period is six months in Panel $\mathrm{C}$ (the resulting overlapping portfolios are equally-weighted). We calculate value-weighted monthly return of each of the resulting nine portfolios. The table shows the portfolios' mean excess monthly returns (in excess of the riskfree rate) and CAPM alpha. All returns and alphas are in percent per month and the corresponding $t$-statistics are in parentheses. The sample period is 1983 to 2009.

\begin{tabular}{|c|c|c|c|c|c|c|c|c|}
\hline & $\overline{\text { VG1 }}$ & VG2 & VG3 & VG3-VG1 & VG1 & VG2 & VG3 & VG3-VG1 \\
\hline & \multicolumn{4}{|c|}{ Excess return } & \multicolumn{4}{|c|}{ CAPM alpha } \\
\hline \multicolumn{9}{|c|}{ Panel A: Distress-risk and size sorted portfolios } \\
\hline S1 (small) & $\begin{array}{c}0.49 \\
(0.85)\end{array}$ & $\begin{array}{c}1.04 \\
(1.90)\end{array}$ & $\begin{array}{c}0.32 \\
(0.58)\end{array}$ & $\begin{array}{c}-0.17 \\
(-0.46)\end{array}$ & $\begin{array}{c}-0.09 \\
(-0.18)\end{array}$ & $\begin{array}{c}0.45 \\
(0.96)\end{array}$ & $\begin{array}{c}-0.20 \\
(-0.41)\end{array}$ & $\begin{array}{c}-0.11 \\
(-0.29)\end{array}$ \\
\hline $\mathrm{S} 2$ & $\begin{array}{l}-0.27 \\
(-0.48)\end{array}$ & $\begin{array}{c}0.19 \\
(0.36)\end{array}$ & $\begin{array}{l}-0.63 \\
(-1.07)\end{array}$ & $\begin{array}{l}-0.36 \\
(-1.24)\end{array}$ & $\begin{array}{c}-0.97 \\
(-2.06)\end{array}$ & $\begin{array}{c}-0.49 \\
(-1.13)\end{array}$ & $\begin{array}{l}-1.33 \\
(-2.74)\end{array}$ & $\begin{array}{c}-0.37 \\
(-1.26)\end{array}$ \\
\hline S3 (big) & $\begin{array}{l}-0.17 \\
(-0.29)\end{array}$ & $\begin{array}{c}0.16 \\
(0.26)\end{array}$ & $\begin{array}{l}-0.97 \\
(-1.52)\end{array}$ & $\begin{array}{l}-0.80 \\
(-2.43)\end{array}$ & $\begin{array}{c}-1.01 \\
(-2.54)\end{array}$ & $\begin{array}{l}-0.70 \\
(-1.62)\end{array}$ & $\begin{array}{l}-1.94 \\
(-4.43)\end{array}$ & $\begin{array}{l}-0.93 \\
(-2.84)\end{array}$ \\
\hline $\mathrm{S} 1-\mathrm{S} 3$ & $\begin{array}{c}0.66 \\
(1.51)\end{array}$ & $\begin{array}{c}0.88 \\
(2.12)\end{array}$ & $\begin{array}{c}1.29 \\
(2.51)\end{array}$ & & $\begin{array}{c}0.91 \\
(2.19)\end{array}$ & $\begin{array}{c}1.15 \\
(2.89)\end{array}$ & $\begin{array}{c}1.74 \\
(3.72)\end{array}$ & \\
\hline
\end{tabular}




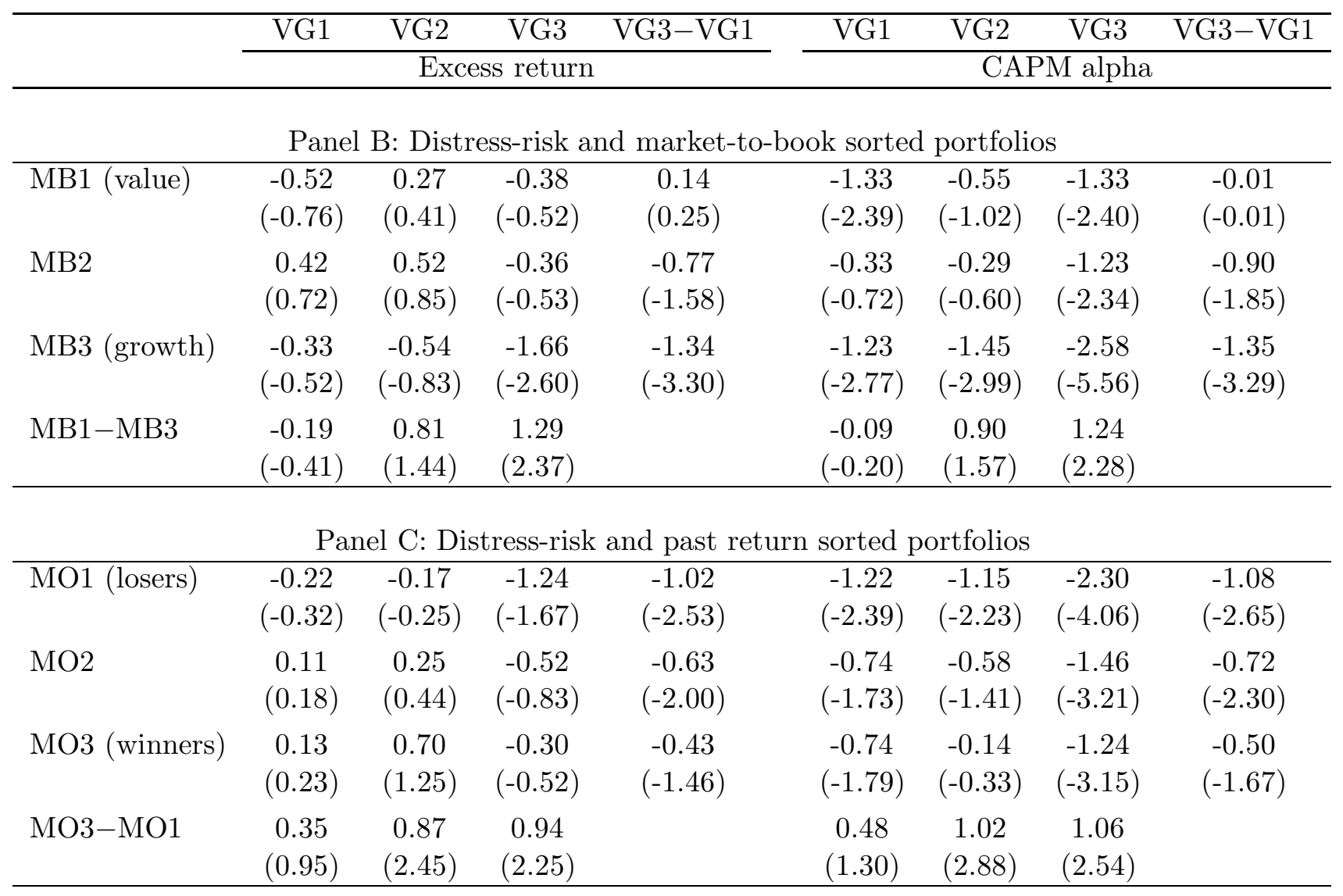


Table 7: Sub-Sample Returns to Value Gap Sorted Portfolios

We sort all stocks into five quintiles (least distressed, D1, to most distressed, D5) based on CHS (2008) distress-risk measure using current market data and quarterly accounting data of the previous quarter. All stock in the D5 quintile (most distressed firms) are further sorted independently into three portfolios based on value gap and three portfolios based on a stock characteristic. Value gap is defined as the absolute value of the log of the ratio of the equity value implied by our valuation model and the actual equity value. Portfolio VG1 has the least value gap while portfolio VG3 has the highest value gap. The stock characteristic is market capitalization ( $\mathrm{S} 1=$ small, $\mathrm{S} 3=\mathrm{big}$ ) in Panel A, market-to-book ratio (MB1=value, MB3=growth) in Panel B, and past six-month returns (MO1=losers, MO3=winners) in Panel C. Market-to-book ratio is calculated as the ratio of current market value divided by book value of previous quarter and we skip one month in calculating the six-month returns. Sorting is done at the end of each calendar quarter and the holding period is three months for Panels A and B. Sorting is done at the end of each month and the holding period is six months in Panel $\mathrm{C}$ (the resulting overlapping portfolios are equally-weighted). We calculate value-weighted monthly return of each of the resulting nine portfolios. The table shows the portfolios' mean excess monthly returns (in excess of the riskfree rate) and CAPM alpha. All returns and alphas are in percent per month and the corresponding $t$-statistics are in parentheses. The table reports returns for only the long-short portfolio sorted on the firm characteristic. The full sample period of 1983 to 2009 is broken up three different ways into subsamples. Recession and expansion periods are based on NBER recession dummy.

\begin{tabular}{|c|c|c|c|c|c|c|}
\hline & $\overline{\text { VG1 }}$ & VG2 & $\overline{\text { VG3 }}$ & VG1 & $\overline{\text { VG2 }}$ & VG3 \\
\hline & \multicolumn{3}{|c|}{ Excess return } & \multicolumn{3}{|c|}{ CAPM alpha } \\
\hline & \multicolumn{6}{|c|}{ Panel A: S1(small)-S3(big) portfolio } \\
\hline Full sample & $\begin{array}{c}0.66 \\
(1.51)\end{array}$ & $\begin{array}{c}0.88 \\
(2.12)\end{array}$ & $\begin{array}{c}1.29 \\
(2.51)\end{array}$ & $\begin{array}{c}0.91 \\
(2.19)\end{array}$ & $\begin{array}{c}1.15 \\
(2.89)\end{array}$ & $\begin{array}{c}1.74 \\
(3.72)\end{array}$ \\
\hline January & $\begin{array}{c}5.45 \\
(3.02)\end{array}$ & $\begin{array}{c}5.93 \\
(3.07)\end{array}$ & $\begin{array}{c}9.50 \\
(4.11)\end{array}$ & $\begin{array}{c}6.16 \\
(3.49)\end{array}$ & $\begin{array}{c}6.43 \\
(3.27)\end{array}$ & $\begin{array}{l}10.25 \\
(4.42)\end{array}$ \\
\hline Non-January & $\begin{array}{c}0.22 \\
(0.50)\end{array}$ & $\begin{array}{c}0.42 \\
(1.04)\end{array}$ & $\begin{array}{c}0.54 \\
(1.09)\end{array}$ & $\begin{array}{c}0.45 \\
(1.08)\end{array}$ & $\begin{array}{c}0.67 \\
(1.75)\end{array}$ & $\begin{array}{c}0.97 \\
(2.20)\end{array}$ \\
\hline Recession & $\begin{array}{c}0.07 \\
(0.05)\end{array}$ & $\begin{array}{l}-0.96 \\
(-0.50)\end{array}$ & $\begin{array}{c}3.59 \\
(1.79)\end{array}$ & $\begin{array}{l}-0.14 \\
(-0.10)\end{array}$ & $\begin{array}{l}-1.51 \\
(-0.80)\end{array}$ & $\begin{array}{c}2.82 \\
(1.47)\end{array}$ \\
\hline Expansion & $\begin{array}{c}0.74 \\
(1.62)\end{array}$ & $\begin{array}{c}1.14 \\
(2.91)\end{array}$ & $\begin{array}{c}0.97 \\
(1.89)\end{array}$ & $\begin{array}{c}1.20 \\
(2.76)\end{array}$ & $\begin{array}{c}1.55 \\
(4.17)\end{array}$ & $\begin{array}{c}1.64 \\
(3.50)\end{array}$ \\
\hline $1980 \mathrm{~s}$ & $\begin{array}{c}0.25 \\
(0.36)\end{array}$ & $\begin{array}{c}0.22 \\
(0.30)\end{array}$ & $\begin{array}{c}0.30 \\
(0.41)\end{array}$ & $\begin{array}{c}0.53 \\
(0.80)\end{array}$ & $\begin{array}{c}0.48 \\
(0.65)\end{array}$ & $\begin{array}{c}0.65 \\
(0.92)\end{array}$ \\
\hline $1990 \mathrm{~s}$ & $\begin{array}{c}0.45 \\
(0.71)\end{array}$ & $\begin{array}{c}1.41 \\
(2.50)\end{array}$ & $\begin{array}{c}1.37 \\
(1.76)\end{array}$ & $\begin{array}{c}1.02 \\
(1.61)\end{array}$ & $\begin{array}{c}2.05 \\
(3.81)\end{array}$ & $\begin{array}{c}2.14 \\
(2.83)\end{array}$ \\
\hline $2000 \mathrm{~s}$ & $\begin{array}{c}1.10 \\
(1.32)\end{array}$ & $\begin{array}{c}0.75 \\
(0.93)\end{array}$ & $\begin{array}{c}1.79 \\
(1.82)\end{array}$ & $\begin{array}{c}1.06 \\
(1.32)\end{array}$ & $\begin{array}{c}0.70 \\
(0.91)\end{array}$ & $\begin{array}{c}1.70 \\
(2.00)\end{array}$ \\
\hline
\end{tabular}




\begin{tabular}{|c|c|c|c|c|c|c|}
\hline & VG1 & VG2 & VG3 & VG1 & VG2 & VG3 \\
\hline & \multicolumn{3}{|c|}{ Excess return } & \multicolumn{3}{|c|}{ CAPM alpha } \\
\hline \multicolumn{7}{|c|}{ Panel B: MB1(value)-MB3(growth) portfolio } \\
\hline Full sample & $\begin{array}{c}-0.19 \\
(-0.41)\end{array}$ & $\begin{array}{c}0.81 \\
(1.44)\end{array}$ & $\begin{array}{c}1.29 \\
(2.37)\end{array}$ & $\begin{array}{c}-0.09 \\
(-0.20)\end{array}$ & $\begin{array}{c}0.90 \\
(1.57)\end{array}$ & $\begin{array}{c}1.24 \\
(2.28)\end{array}$ \\
\hline January & $\begin{array}{c}-1.35 \\
(-0.67)\end{array}$ & $\begin{array}{c}1.14 \\
(0.52)\end{array}$ & $\begin{array}{c}5.37 \\
(2.21)\end{array}$ & $\begin{array}{c}-1.26 \\
(-0.60)\end{array}$ & $\begin{array}{c}1.47 \\
(0.65)\end{array}$ & $\begin{array}{c}5.58 \\
(2.20)\end{array}$ \\
\hline Non-January & $\begin{array}{c}-0.08 \\
(-0.18)\end{array}$ & $\begin{array}{c}0.79 \\
(1.34)\end{array}$ & $\begin{array}{c}0.92 \\
(1.68)\end{array}$ & $\begin{array}{c}0.01 \\
(0.02)\end{array}$ & $\begin{array}{c}0.85 \\
(1.45)\end{array}$ & $\begin{array}{c}0.87 \\
(1.58)\end{array}$ \\
\hline Recession & $\begin{array}{c}0.85 \\
(0.48)\end{array}$ & $\begin{array}{c}0.82 \\
(0.39)\end{array}$ & $\begin{array}{c}1.49 \\
(0.58)\end{array}$ & $\begin{array}{c}0.75 \\
(0.42)\end{array}$ & $\begin{array}{c}0.71 \\
(0.33)\end{array}$ & $\begin{array}{c}2.17 \\
(0.85)\end{array}$ \\
\hline Expansion & $\begin{array}{c}-0.33 \\
(-0.72)\end{array}$ & $\begin{array}{c}0.81 \\
(1.41)\end{array}$ & $\begin{array}{c}1.26 \\
(2.48)\end{array}$ & $\begin{array}{c}-0.18 \\
(-0.38)\end{array}$ & $\begin{array}{c}0.95 \\
(1.62)\end{array}$ & $\begin{array}{c}1.33 \\
(2.57)\end{array}$ \\
\hline $1980 \mathrm{~s}$ & $\begin{array}{c}-1.43 \\
(-1.86)\end{array}$ & $\begin{array}{c}-0.73 \\
(-1.03)\end{array}$ & $\begin{array}{c}1.64 \\
(1.80)\end{array}$ & $\begin{array}{c}-1.48 \\
(-1.89)\end{array}$ & $\begin{array}{c}-0.64 \\
(-0.88)\end{array}$ & $\begin{array}{c}1.57 \\
(1.69)\end{array}$ \\
\hline $1990 \mathrm{~s}$ & $\begin{array}{l}-1.11 \\
(-1.88)\end{array}$ & $\begin{array}{c}-0.06 \\
(-0.07)\end{array}$ & $\begin{array}{c}1.75 \\
(2.21)\end{array}$ & $\begin{array}{c}-0.95 \\
(-1.56)\end{array}$ & $\begin{array}{c}0.35 \\
(0.43)\end{array}$ & $\begin{array}{c}1.91 \\
(2.33)\end{array}$ \\
\hline $2000 s$ & $\begin{array}{c}1.47 \\
(1.61)\end{array}$ & $\begin{array}{c}2.61 \\
(2.28)\end{array}$ & $\begin{array}{c}0.61 \\
(0.59)\end{array}$ & $\begin{array}{c}1.45 \\
(1.59)\end{array}$ & $\begin{array}{c}2.61 \\
(2.27)\end{array}$ & $\begin{array}{c}0.63 \\
(0.61)\end{array}$ \\
\hline \multicolumn{7}{|c|}{ Panel C: MO3(winners)-MO1(losers) portfolio } \\
\hline Full sample & $\begin{array}{c}0.35 \\
(0.95)\end{array}$ & $\begin{array}{c}0.87 \\
(2.45)\end{array}$ & $\begin{array}{c}0.94 \\
(2.25)\end{array}$ & $\begin{array}{c}0.48 \\
(1.30)\end{array}$ & $\begin{array}{c}1.02 \\
(2.88)\end{array}$ & $\begin{array}{c}1.06 \\
(2.54)\end{array}$ \\
\hline January & $\begin{array}{c}0.15 \\
(0.09)\end{array}$ & $\begin{array}{l}-1.46 \\
(-1.18)\end{array}$ & $\begin{array}{c}-2.70 \\
(-1.90)\end{array}$ & $\begin{array}{c}0.65 \\
(0.38)\end{array}$ & $\begin{array}{l}-1.00 \\
(-0.80)\end{array}$ & $\begin{array}{c}-2.92 \\
(-1.97)\end{array}$ \\
\hline Non-January & $\begin{array}{c}0.37 \\
(0.98)\end{array}$ & $\begin{array}{c}1.08 \\
(2.93)\end{array}$ & $\begin{array}{c}1.27 \\
(2.94)\end{array}$ & $\begin{array}{c}0.48 \\
(1.27)\end{array}$ & $\begin{array}{c}1.21 \\
(3.28)\end{array}$ & $\begin{array}{c}1.39 \\
(3.24)\end{array}$ \\
\hline Recession & $\begin{array}{c}-1.36 \\
(-0.96)\end{array}$ & $\begin{array}{c}1.11 \\
(0.93)\end{array}$ & $\begin{array}{c}0.36 \\
(0.18)\end{array}$ & $\begin{array}{c}-2.01 \\
(-1.54)\end{array}$ & $\begin{array}{c}0.56 \\
(0.51)\end{array}$ & $\begin{array}{c}-0.73 \\
(-0.43)\end{array}$ \\
\hline Expansion & $\begin{array}{c}0.60 \\
(1.62)\end{array}$ & $\begin{array}{c}0.84 \\
(2.26)\end{array}$ & $\begin{array}{c}1.02 \\
(2.64)\end{array}$ & $\begin{array}{c}0.71 \\
(1.88)\end{array}$ & $\begin{array}{c}0.98 \\
(2.60)\end{array}$ & $\begin{array}{c}0.99 \\
(2.49)\end{array}$ \\
\hline $1980 \mathrm{~s}$ & $\begin{array}{c}0.63 \\
(1.37)\end{array}$ & $\begin{array}{c}0.39 \\
(0.75)\end{array}$ & $\begin{array}{c}0.63 \\
(1.15)\end{array}$ & $\begin{array}{c}0.51 \\
(1.09)\end{array}$ & $\begin{array}{c}0.62 \\
(1.22)\end{array}$ & $\begin{array}{c}0.54 \\
(0.96)\end{array}$ \\
\hline $1990 \mathrm{~s}$ & $\begin{array}{c}0.89 \\
(2.27)\end{array}$ & $\begin{array}{c}1.51 \\
(3.40)\end{array}$ & $\begin{array}{c}1.06 \\
(2.04)\end{array}$ & $\begin{array}{c}1.01 \\
(2.50)\end{array}$ & $\begin{array}{c}1.47 \\
(3.20)\end{array}$ & $\begin{array}{c}0.81 \\
(1.52)\end{array}$ \\
\hline $2000 \mathrm{~s}$ & $\begin{array}{c}-0.33 \\
(-0.41)\end{array}$ & $\begin{array}{c}0.48 \\
(0.66)\end{array}$ & $\begin{array}{c}0.98 \\
(1.12)\end{array}$ & $\begin{array}{c}-0.38 \\
(-0.49)\end{array}$ & $\begin{array}{c}0.44 \\
(0.63)\end{array}$ & $\begin{array}{c}0.92 \\
(1.12)\end{array}$ \\
\hline
\end{tabular}




\section{Table 8: Longer Horizon Returns to Value Gap Sorted Portfolios}

We sort all stocks into five quintiles (least distressed, D1, to most distressed, D5) based on CHS (2008) distress-risk measure using current market data and quarterly accounting data of the previous quarter. All stock in the D5 quintile (most distressed firms) are further sorted independently into three portfolios based on value gap and three portfolios based on a stock characteristic. Value gap is defined as the absolute value of the log of the ratio of the equity value implied by our valuation model and the actual equity value. Portfolio VG1 has the least value gap while portfolio VG3 has the highest value gap. The stock characteristic is market capitalization ( $\mathrm{S} 1=$ small, $\mathrm{S} 3=\mathrm{big}$ ) in Panel A, market-to-book ratio (MB1=value, MB3=growth) in Panel $\mathrm{B}$, and past six-month returns (MO1=losers, MO3=winners) in Panel C. Market-to-book ratio is calculated as the ratio of current market value divided by book value of previous quarter and we skip one month in calculating the six-month returns. Sorting is done at the end of each calendar quarter and the holding period is six, 12, and 18 months for Panels A and B. Sorting is done at the end of each month and the holding period is 12 and 18 months months in Panel C. All resulting overlapping portfolios are equallyweighted. We calculate value-weighted monthly return of each of the resulting nine portfolios. The resulting overlapping portfolios are equally-weighted. The table shows the portfolios' mean excess monthly returns (in excess of the riskfree rate) and CAPM alpha. All returns and alphas are in percent per month and the corresponding $t$-statistics are in parentheses. The table reports returns for only the long-short portfolio sorted on the firm characteristic. The sample period is 1983 to 2009.

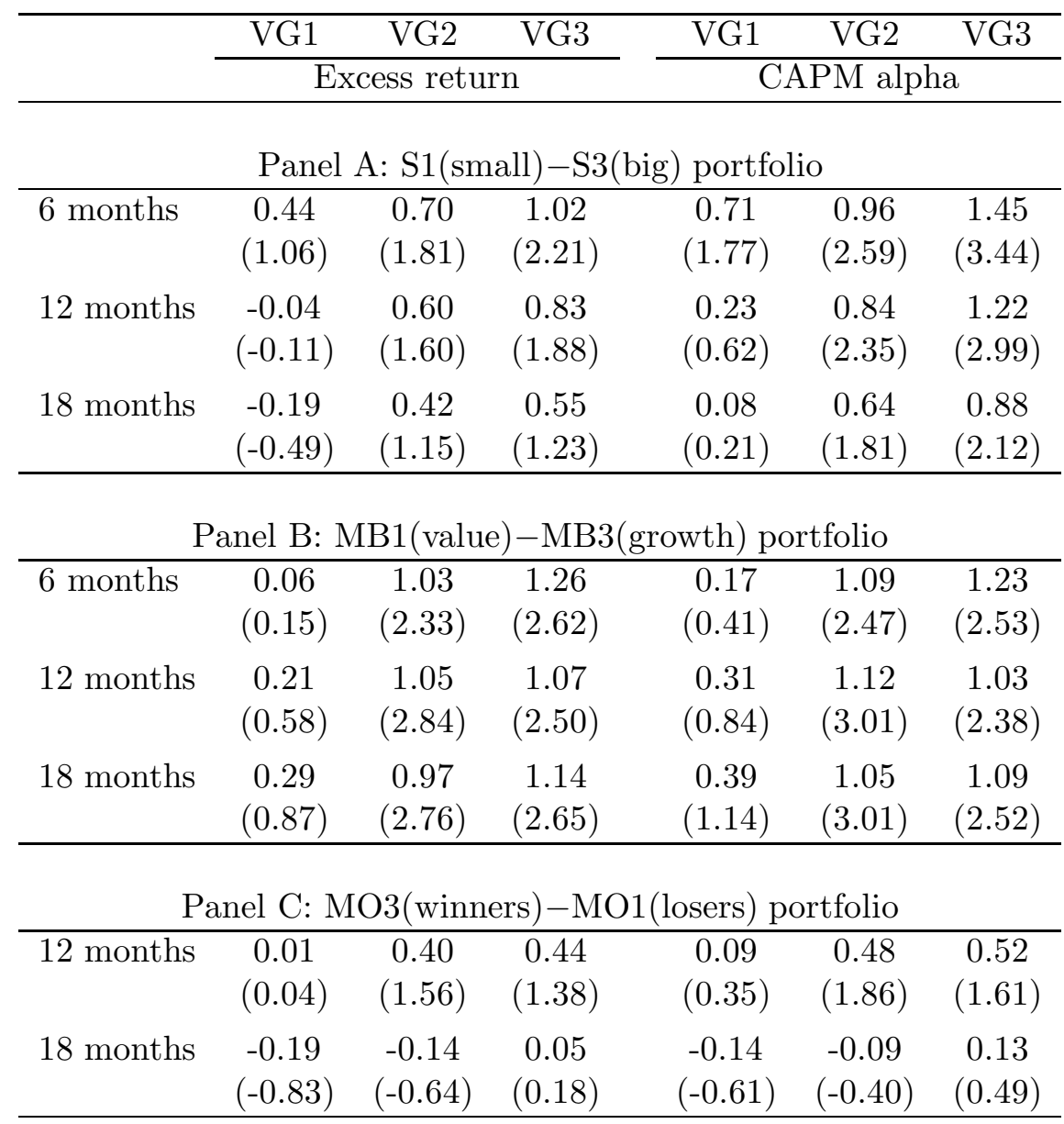




\section{Table 9: Returns to Value Gap Sorted Portfolios for Different Distress Measures}

We separate distress firms from the rest of stocks based on four different distress risk measures. These are (i) CHS (2008) distress-risk measure using current market data and quarterly accounting data of the previous quarter (distress firms are those in the quintile with the highest measure), (ii) KMV measure using quarterly data on short- and long-term liabilities (distressed firms are those with KMV's probability of bankruptcy higher than 0.25), (iii) Credit rating based on S\&P longterm bond rating (distressed firms are those with rating of $\mathrm{BB}+$ and lower), and (iv) Z-score based on Altman (1968) using quarterly accounting data (distressed firms are those with Z-score lower than 1.81). All distressed stocks are further sorted independently into three portfolios based on value gap and three portfolios based on a stock characteristic. Value gap is defined as the absolute value of the log of the ratio of the equity value implied by our valuation model and the actual equity value. Portfolio VG1 has the least value gap while portfolio VG3 has the highest value gap. The stock characteristic is market capitalization ( $\mathrm{S} 1=$ small, $\mathrm{S} 3=\mathrm{big})$ in Panel A, market-to-book ratio $(\mathrm{MB1}=$ value, $\mathrm{MB} 3=$ growth $)$ in Panel $\mathrm{B}$, and past six-month returns (MO1=losers, MO3=winners) in Panel C. Market-to-book ratio is calculated as the ratio of current market value divided by book value of previous quarter and we skip one month in calculating the six-month returns. Sorting is done at the end of each calendar quarter and the holding period is three months for Panels A and B. Sorting is done at the end of each month and the holding period is six months in Panel C (the resulting overlapping portfolios are equally-weighted). We calculate value-weighted monthly return of each of the resulting nine portfolios. The table shows the portfolios' mean excess monthly returns (in excess of the riskfree rate) and CAPM alpha. All returns and alphas are in percent per month and the corresponding $t$-statistics are in parentheses. The table reports returns for only the long-short portfolio sorted on the firm characteristic. The sample period is 1983 to 2009, except for credit rating based measures, where it is 1987 to 2009.

\begin{tabular}{|c|c|c|c|c|c|c|}
\hline & VG1 & VG2 & VG3 & VG1 & VG2 & VG3 \\
\hline & \multicolumn{3}{|c|}{ Excess return } & \multicolumn{3}{|c|}{ CAPM alpha } \\
\hline \multicolumn{7}{|c|}{ Panel A: S1(small)-S3(big) portfolio } \\
\hline CHS & $\begin{array}{c}0.66 \\
(1.51)\end{array}$ & $\begin{array}{c}0.88 \\
(2.12)\end{array}$ & $\begin{array}{c}1.29 \\
(2.51)\end{array}$ & $\begin{array}{c}0.91 \\
(2.19)\end{array}$ & $\begin{array}{c}1.15 \\
(2.89)\end{array}$ & $\begin{array}{c}1.74 \\
(3.72)\end{array}$ \\
\hline KMV & $\begin{array}{c}0.19 \\
(0.47)\end{array}$ & $\begin{array}{c}0.13 \\
(0.37)\end{array}$ & $\begin{array}{c}0.66 \\
(1.59)\end{array}$ & $\begin{array}{c}0.32 \\
(0.79)\end{array}$ & $\begin{array}{c}0.27 \\
(0.75)\end{array}$ & $\begin{array}{c}0.90 \\
(2.25)\end{array}$ \\
\hline Credit rating & $\begin{array}{c}-0.33 \\
(-0.90)\end{array}$ & $\begin{array}{c}-0.25 \\
(-0.65)\end{array}$ & $\begin{array}{c}0.30 \\
(0.65)\end{array}$ & $\begin{array}{c}-0.36 \\
(-0.98)\end{array}$ & $\begin{array}{c}-0.13 \\
(-0.34)\end{array}$ & $\begin{array}{c}0.43 \\
(0.93)\end{array}$ \\
\hline Z-score & $\begin{array}{l}-0.05 \\
(-0.14)\end{array}$ & $\begin{array}{c}0.37 \\
(0.95)\end{array}$ & $\begin{array}{c}0.75 \\
(1.88)\end{array}$ & $\begin{array}{c}-0.26 \\
(-0.70)\end{array}$ & $\begin{array}{c}0.33 \\
(0.84)\end{array}$ & $\begin{array}{c}0.64 \\
(1.60)\end{array}$ \\
\hline
\end{tabular}




\begin{tabular}{|c|c|c|c|c|c|c|}
\hline & VG1 & VG2 & VG3 & VG1 & VG2 & VG3 \\
\hline & \multicolumn{3}{|c|}{ Excess return } & \multicolumn{3}{|c|}{ CAPM alpha } \\
\hline \multicolumn{7}{|c|}{ Panel B: MB1(value)-MB3(growth) portfolio } \\
\hline CHS & $\begin{array}{c}-0.19 \\
(-0.41)\end{array}$ & $\begin{array}{c}0.81 \\
(1.44)\end{array}$ & $\begin{array}{c}1.29 \\
(2.37)\end{array}$ & $\begin{array}{c}-0.09 \\
(-0.20)\end{array}$ & $\begin{array}{c}0.90 \\
(1.57)\end{array}$ & $\begin{array}{c}1.24 \\
(2.28)\end{array}$ \\
\hline KMV & $\begin{array}{c}0.01 \\
(0.03)\end{array}$ & $\begin{array}{c}0.43 \\
(1.15)\end{array}$ & $\begin{array}{c}0.99 \\
(2.40)\end{array}$ & $\begin{array}{c}-0.07 \\
(-0.20)\end{array}$ & $\begin{array}{c}0.47 \\
(1.25)\end{array}$ & $\begin{array}{c}0.95 \\
(2.29)\end{array}$ \\
\hline Credit rating & $\begin{array}{c}0.19 \\
(0.52)\end{array}$ & $\begin{array}{c}0.10 \\
(0.22)\end{array}$ & $\begin{array}{c}0.50 \\
(1.16)\end{array}$ & $\begin{array}{c}0.15 \\
(0.40)\end{array}$ & $\begin{array}{c}0.15 \\
(0.34)\end{array}$ & $\begin{array}{c}0.52 \\
(1.19)\end{array}$ \\
\hline Z-score & $\begin{array}{c}0.11 \\
(0.23)\end{array}$ & $\begin{array}{c}0.29 \\
(0.69)\end{array}$ & $\begin{array}{c}0.37 \\
(0.73)\end{array}$ & $\begin{array}{c}0.08 \\
(0.16)\end{array}$ & $\begin{array}{c}0.33 \\
(0.79)\end{array}$ & $\begin{array}{c}0.55 \\
(1.09)\end{array}$ \\
\hline \multicolumn{7}{|c|}{ Panel C: MO3(winners)-MO1(losers) portfolio } \\
\hline CHS & $\begin{array}{c}0.35 \\
(0.95)\end{array}$ & $\begin{array}{c}0.87 \\
(2.45)\end{array}$ & $\begin{array}{c}0.94 \\
(2.25)\end{array}$ & $\begin{array}{c}0.48 \\
(1.30)\end{array}$ & $\begin{array}{c}1.02 \\
(2.88)\end{array}$ & $\begin{array}{c}1.06 \\
(2.54)\end{array}$ \\
\hline KMV & $\begin{array}{c}0.59 \\
(1.96)\end{array}$ & $\begin{array}{c}0.71 \\
(2.20)\end{array}$ & $\begin{array}{c}0.62 \\
(1.68)\end{array}$ & $\begin{array}{c}0.68 \\
(2.25)\end{array}$ & $\begin{array}{c}0.80 \\
(2.46)\end{array}$ & $\begin{array}{c}0.75 \\
(2.01)\end{array}$ \\
\hline Credit rating & $\begin{array}{c}0.52 \\
(1.61)\end{array}$ & $\begin{array}{c}0.76 \\
(1.70)\end{array}$ & $\begin{array}{c}1.27 \\
(3.06)\end{array}$ & $\begin{array}{c}0.66 \\
(2.10)\end{array}$ & $\begin{array}{c}0.81 \\
(1.80)\end{array}$ & $\begin{array}{c}1.44 \\
(3.55)\end{array}$ \\
\hline Z-score & $\begin{array}{c}0.46 \\
(1.32)\end{array}$ & $\begin{array}{c}0.32 \\
(0.88)\end{array}$ & $\begin{array}{c}0.92 \\
(2.25)\end{array}$ & $\begin{array}{c}0.65 \\
(1.91)\end{array}$ & $\begin{array}{c}0.53 \\
(1.47)\end{array}$ & $\begin{array}{c}1.18 \\
(3.00)\end{array}$ \\
\hline
\end{tabular}


Table 10: Characteristics of Fairly Valued and Misvalued Distressed Stocks

Each calendar quarter, we sort all stocks into five quintiles (least distressed, D1, to most distressed, D5) based on CHS (2008) distress-risk measure using current market data and quarterly accounting data of the previous quarter. All stock in the D5 quintile (most distressed firms) are further sorted into five equal-sized portfolios based on our valuation model. The second sorting is done based on value gap (VG1=most fairly valued, VG5=most misvalued). Value gap is defined as the absolute value of the log of the ratio of the equity value implied by our valuation model and the actual equity value. Number of observations is the number of firm-months in the respective quintiles. Share turnover is trading volume scaled by total shares outstanding. Amihud illiquidity is the monthly average of daily ratios of absolute return to dollar trading volume (in millions). Standard deviation of daily stock returns (reported in percent) is based market-adjusted stock return in the past year. Institutional ownership (reported in percent) is the sum of all shares held by institutions divided by total shares outstanding. Number of analysts covering the firm is measured by the number of forecasts appearing in IBES. Standard deviation of analysts' forecasts is also calculated from IBES data. Percent of firms with negative earnings is based on the net income in the previous calendar year. The table shows the mean and median for each variable. The sample period is 1983 to 2009 .

\begin{tabular}{llccccc}
\hline & & VG1 & VG2 & VG3 & VG4 & VG5 \\
\hline NumObs & & 39,504 & 39,552 & 39,646 & 39,646 & 38,374 \\
Share turnover & Mean & 0.09 & 0.09 & 0.08 & 0.08 & 0.10 \\
& Median & 0.04 & 0.04 & 0.04 & 0.04 & 0.04 \\
Amihud illiquidity & Mean & 21.84 & 24.07 & 29.10 & 33.26 & 28.99 \\
& Median & 1.90 & 2.29 & 3.02 & 3.55 & 1.71 \\
Stdev of stock returns & Mean & 6.53 & 6.51 & 6.61 & 6.78 & 6.85 \\
& Median & 5.99 & 5.96 & 6.09 & 6.18 & 6.22 \\
Institutional ownership & Mean & 19.01 & 19.07 & 19.37 & 18.70 & 19.10 \\
& Median & 10.45 & 10.69 & 11.20 & 10.87 & 10.92 \\
Number of analysts & Mean & 2.61 & 2.49 & 2.38 & 2.23 & 2.61 \\
\multirow{3}{*}{ Stdev of analysts' forecasts } & Median & 1.50 & 1.50 & 1.50 & 1.38 & 1.58 \\
& Mean & 10.05 & 9.87 & 10.83 & 10.72 & 16.03 \\
\% of negative earnings & 4.75 & 4.92 & 5.50 & 5.75 & 8.00 \\
& Mean & 80.6 & 78.6 & 75.6 & 74.6 & 86.3 \\
& Median & 100.0 & 100.0 & 100.0 & 100.0 & 100.0 \\
\hline
\end{tabular}




\section{Figure 1: Cumulative CAPM Alphas for Value Gap Sorted Portfolios}

We sort all stocks into five quintiles (least distressed, D1, to most distressed, D5) based on CHS (2008) distress-risk measure using current market data and quarterly accounting data of the previous quarter. All stock in the D5 quintile (most distressed firms) are further sorted independently into three portfolios based on value gap and three portfolios based on a stock characteristic. Value gap is defined as the absolute value of the log of the ratio of the equity value implied by our valuation model and the actual equity value. Portfolio VG1 has the least value gap while portfolio VG3 has the highest value gap. The stock characteristic is market capitalization ( $\mathrm{S} 1=$ small, $\mathrm{S} 3=\mathrm{big}$ ) in Panel A, market-to-book ratio (MB1=value, MB3=growth) in Panel B, and past six-month returns (MO1=losers, MO3=winners) in Panel C. Market-to-book ratio is calculated as the ratio of current market value divided by book value of previous quarter and we skip one month in calculating the six-month returns. Sorting is done at the end of each calendar quarter and the holding period is three months for Panels A and B. Sorting is done at the end of each month and the holding period is six months in Panel $\mathrm{C}$ (the resulting overlapping portfolios are equally-weighted). We calculate value-weighted monthly return of each of the resulting nine portfolios. The figure shows the cumulative CAPM alphas for the long-short portfolio sorted on the firm characteristic. The sample period is 1983 to 2009.

\section{Panel A: S1(small)-S3(big) portfolio}

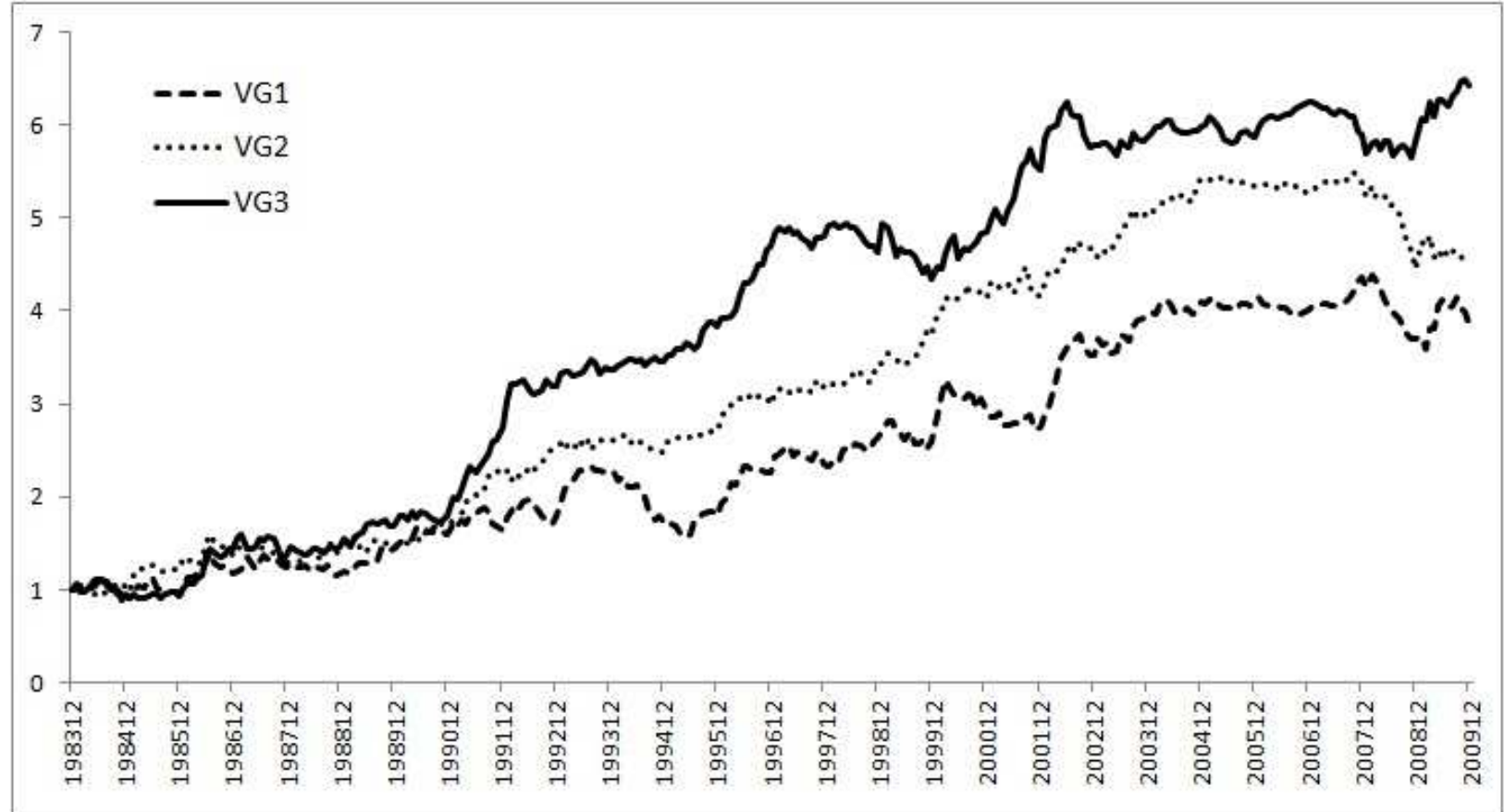


Panel B: MB1(value)-MB3(growth) portfolio

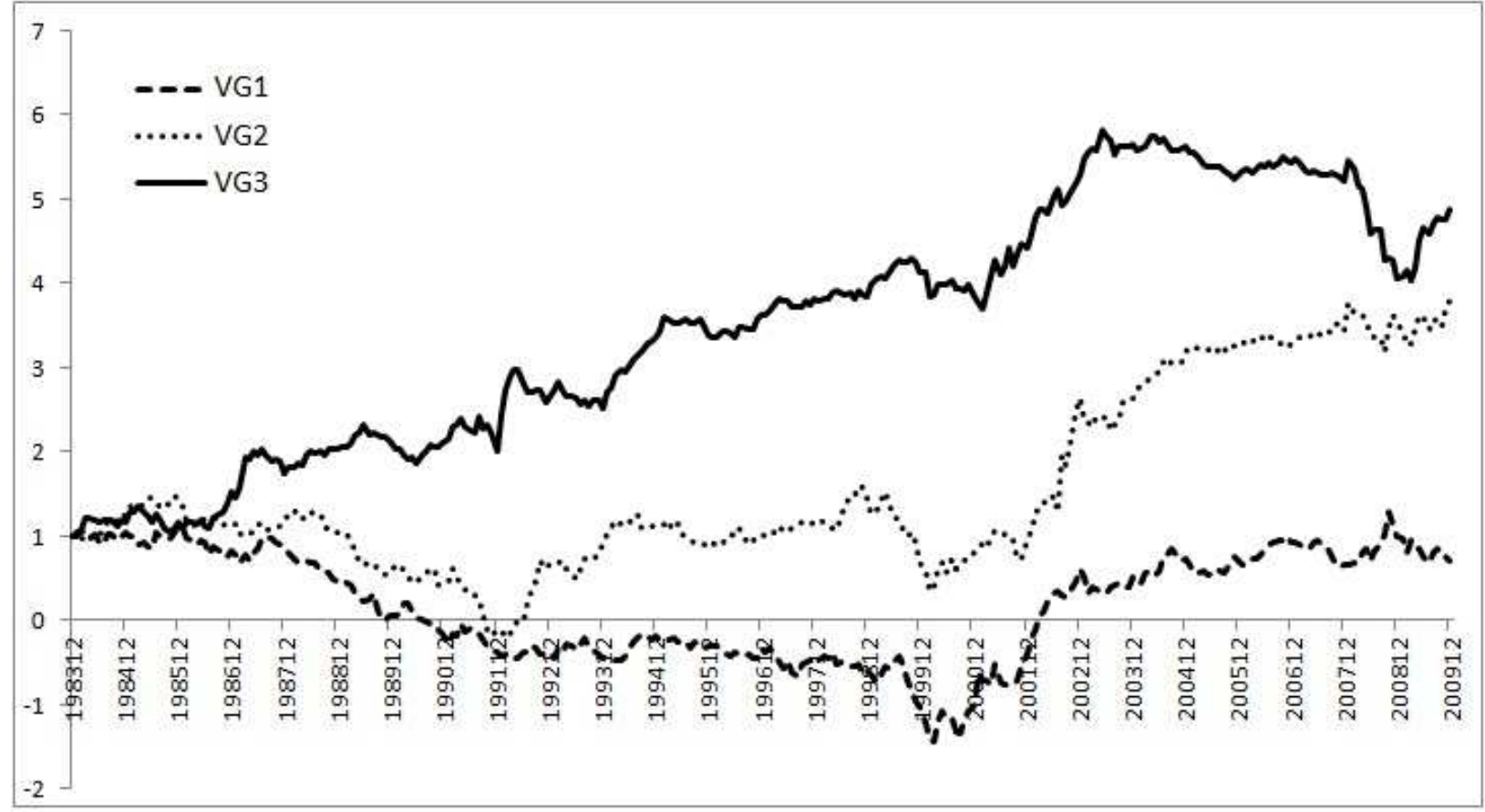

Panel C: MO3(winners)-MO1(losers) portfolio

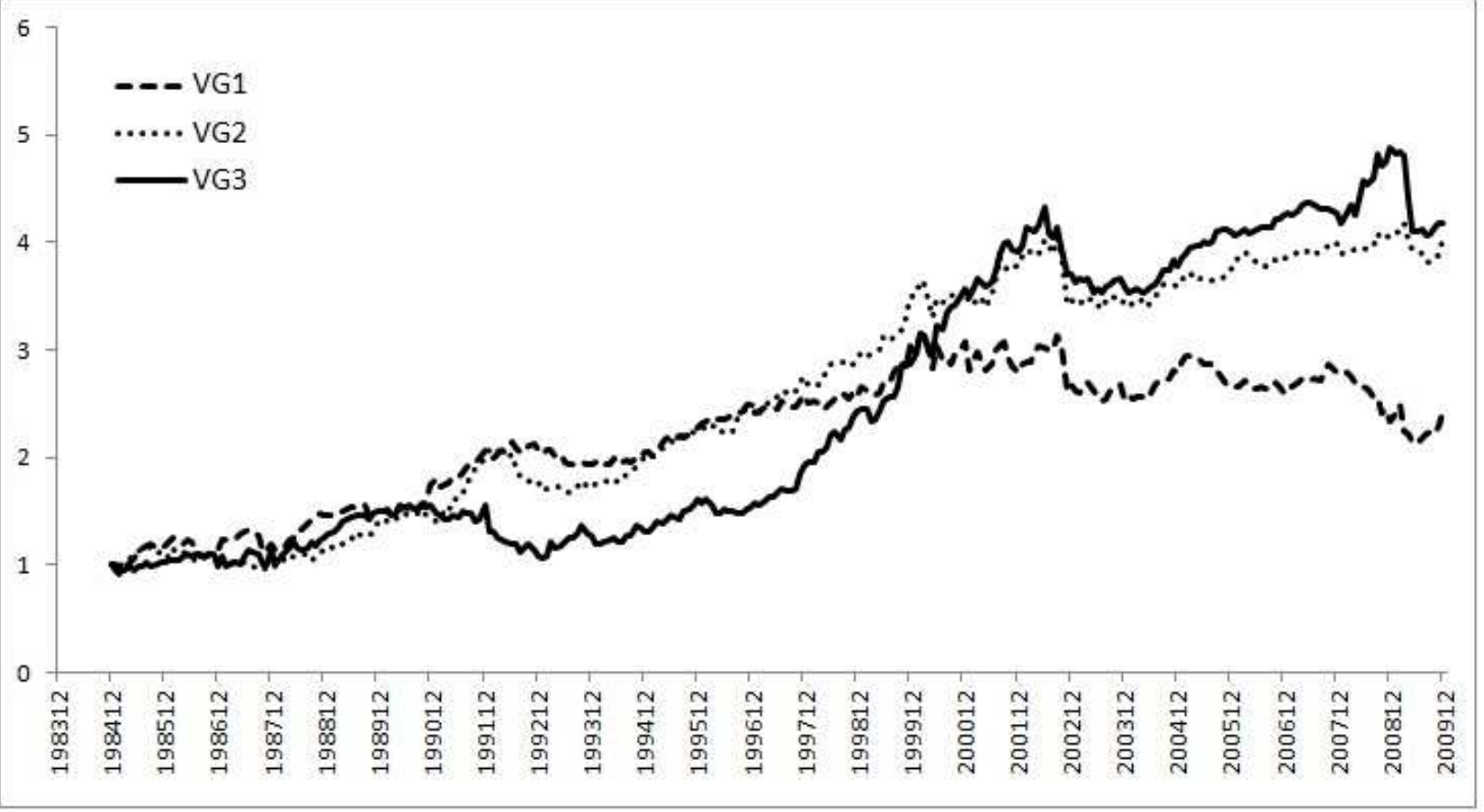

